\title{
28 Research Suare \\ Effects of land conversion on soil microbial community structure and diversity
}

\author{
Tong Zhang \\ Heilongjiang University \\ Yufei Liu \\ Heilongjiang University \\ xin Sui \\ Heilongjiang University \\ fuqiang Song ( $D$ 0431sfq@163.com )
}

\section{Research article}

Keywords: Black soil of Northeast; land use; high-throughput sequencing; microbial community; environmental factors

Posted Date: August 22nd, 2020

DOl: https://doi.org/10.21203/rs.3.rs-33038/v2

License: (c) (1) This work is licensed under a Creative Commons Attribution 4.0 International License. Read Full License 


\section{Abstract}

Background: To study the impact of land-use change on soil microbial community structure and diversity in Northeast China, three typical land-use types (plough, grassland, and forest), grassland change to forest land and grassland change to plough, in the Qiqihar region of Heilongjiang Province were taken as research objects. Methods : MiSeq high-throughput sequencing technology based on bacterial 16S rRNA and fungal ITS rRNA was used to study the above community structure of soil bacteria and fungi and to explore the relationship between soil bacteria and soil environmental factors. Results : The results showed that the dominant bacterial phyla changed from Actinobacteria to Acidobacteria , the dominant fungal phyla changed from Ascomycetes to Basidiomycetes, and the ECM functional group increased significantly after the grassland was completely changed to forest land. After the grassland was changed to plough, the dominant phyla changed from Actinomycetes to Proteobacteria. The functional groups of pathogens and parasites increased significantly. There was no significant difference in the diversity of soil bacterial communities, and the diversity of fungal communities increased significantly. CCA showed that $\mathrm{pH}, \mathrm{MC}, \mathrm{NO} 3--\mathrm{N}$, TP and AP of soil were important factors affecting the composition of soil microbial communities, and changes in land-use patterns changed the physical and chemical properties of soils, thereby affecting the structure and diversity of microbial communities. Conclusions : Our research results clarify the impact of changes in land use on the characteristics of soil microbial communities and provide basic data on the healthy use of land.

\section{Background}

The soil microbial community is the main driving force of ecosystem processes and has the functions of completing the decomposition of soil organic matter and plant litter and mediating the carbon (C) and nitrogen $(\mathrm{N})$ biogeochemical cycles in terrestrial ecosystems ${ }^{[1,2]}$. However, the composition and diversity of these communities are largely controlled by soil environmental conditions. Therefore, understanding the composition and diversity of soil microbial communities can reveal the interrelationships between soil microorganisms and the local environment and how these communities respond to human disturbance ${ }^{[3]}$.

Land-use transformation dominated by human activities has a significant impact on the composition and structure of soil microbial communities ${ }^{[4,5]}$. It can fundamentally change soil quality and nutrient cycling, thereby affecting the construction of soil microbial communities, and it can potentially affect soil microbial diversity and ecosystem functions ${ }^{[6,7]}$. For example, Jangid et al. ${ }^{[8]}$ found that grassland conversion to plough caused significant changes in bacterial and fungal abundance and diversity and determined that land-use change was the main determinant of microbial community composition. Wang et al. ${ }^{[9]}$ found that after grassland was transformed into pine forest, the dominant soil bacterial phylum changed from Proteus to Actinomycetes, the dominant fungal phylum changed from Ascomycetes to Basidiomycetes, and grassland afforestation increased ECM fungi but reduced biological nutrition fungus. Mendes et al. ${ }^{[10]}$ found that the contents of acidophilus bacteria and chlamydia in forest soil 
were higher, the content of actinomycetes in forest logging areas was higher, and the content of nitrifying bacteria and thermophilus bacteria in plough was higher.

Heilongjiang Province, as China's largest commercial grain production base, has fertile soil and a long history of farming. It's soil physical and chemical properties and fertility are crucial to the sustainable development of agriculture ${ }^{[11]}$. Since the 1950 s, with the increase in population, to solve the problems of food and clothing, the area has adopted land reclamation to obtain ploughs. The original grassland was reclaimed into plough, and the natural vegetation disappeared. When the plough land was abandoned, the ground was exposed, which seriously damaged the soil, and it was difficult to restore the original plant community in a short period ${ }^{[12]}$. At the beginning of the 21 st century, the government realized the severity of the ecological and environmental problems and planted some grassland and abandoned land with forest to protect the fragile local ecological environment and promote sustainable and stable economic development ${ }^{[13,14]}$. In this paper, in the western region of Heilongjiang Province was chosen as the study area, and three land-use types-grass, plough, forest land-were used to determine how longterm land use changed the soil physical and chemical properties and soil bacterial and fungal community structure and diversity; this information is important for the maintenance of soil fertility in the study area, for breeding and for providing a scientific basis for the protection of soil microbial diversity.

\section{Results}

\section{Physical and chemical properties of soil in different land-use patterns}

The physical and chemical properties of the soil of the three land-use patterns are shown in Table 1. The $\mathrm{pH}$ of all soils was relatively alkaline, with a significant difference between grassland and plough $(\mathrm{P}<0.05)$, with the lowest $\mathrm{pH}$ value in plough and the highest $\mathrm{pH}$ value in grassland. The soil moisture content of the three land-use patterns was significantly different $(P<0.05)$, with the highest soil moisture content in forest. The contents of microbial biomass carbon, microbial biomass nitrogen, total phosphorus, available phosphorus and nitrate nitrogen in plough were significantly higher than those in forest and grassland $(P<0.05)$. However, there was no significant difference in soil organic matter, total nitrogen, ammonium nitrogen, total potassium or available potassium.

Table 1 Physical and chemical properties of soil in different land use patterns

\begin{tabular}{ccccccc}
\hline Land use patterns & $\mathrm{pH}$ value & $\mathrm{MC} \square \% \square$ & $\begin{array}{c}\mathrm{MBC} \\
/(\mathrm{mg} / \mathrm{kg})\end{array}$ & $\begin{array}{c}\mathrm{MBN} \\
/(\mathrm{mg} / \mathrm{kg})\end{array}$ & $\begin{array}{c}\mathrm{SOC} \\
/(\mathrm{g} / \mathrm{kg})\end{array}$ & $\begin{array}{c}\mathrm{TN} \\
/(\mathrm{g} / \mathrm{kg})\end{array}$ \\
\hline Forest & $9.09 \pm 0.07 \mathrm{ab}$ & $14.19 \pm 0.52 \mathrm{a}$ & $140.89 \pm 36.51 \mathrm{~b}$ & $12.48 \pm 3.43 \mathrm{~b}$ & $2.01 \pm 0.51 \mathrm{a}$ & $5.06 \pm 2.03 \mathrm{a}$ \\
Grassland & $9.23 \pm 0.26 \mathrm{a}$ & $13.66 \pm 0.27 \mathrm{~b}$ & $154.65 \pm 52.63 \mathrm{~b}$ & $9.33 \pm 5.03 \mathrm{~b}$ & $2.17 \pm 0.51 \mathrm{a}$ & $5.29 \pm 2.77 \mathrm{a}$ \\
Plough & $8.96 \pm 0.11 \mathrm{~b}$ & $13.48 \pm 0.82 \mathrm{~b}$ & $227.49 \pm 69.93 \mathrm{a}$ & $19.59 \pm 6.33 \mathrm{a}$ & $2.06 \pm 0.08 \mathrm{a}$ & $4.34 \pm 1.11 \mathrm{a}$ \\
\hline
\end{tabular}




\begin{tabular}{ccccccc}
\hline Land use patterns & $\begin{array}{c}\mathrm{NH}_{4}{ }^{+}-\mathrm{N} \\
/(\mathrm{mg} / \mathrm{kg})\end{array}$ & $\begin{array}{c}\mathrm{NO}_{3}{ }^{\mathrm{N}}-\mathrm{N} \\
/(\mathrm{mg} / \mathrm{kg})\end{array}$ & $\begin{array}{c}\mathrm{TP} \\
/(\mathrm{g} / \mathrm{kg})\end{array}$ & $\begin{array}{c}\mathrm{TK} \\
/(\mathrm{mg} / \mathrm{kg})\end{array}$ & $\begin{array}{c}\mathrm{AP} \\
/(\mathrm{mg} / \mathrm{kg})\end{array}$ & $\begin{array}{c}\mathrm{AK} \\
/(\mathrm{mg} / \mathrm{kg})\end{array}$ \\
\hline Forest & $2.76 \pm 0.42 \mathrm{a}$ & $5.44 \pm 2.41 \mathrm{~b}$ & $0.51 \pm 0.05 \mathrm{~b}$ & $4.02 \pm 1.31 \mathrm{a}$ & $5.71 \pm 1.74 \mathrm{~b}$ & $22.14 \pm 6.73 \mathrm{a}$ \\
Grassland & $2.37 \pm 0.23 \mathrm{a}$ & $2.93 \pm 0.79 \mathrm{c}$ & $0.43 \pm 0.07 \mathrm{c}$ & $3.24 \pm 1.71 \mathrm{a}$ & $4.51 \pm 1.79 \mathrm{~b}$ & $20.09 \pm 2.51 \mathrm{a}$ \\
Plough & $2.56 \pm 0.35 \mathrm{a}$ & $11.42 \pm 2.33 \mathrm{a}$ & $0.74 \pm 0.07 \mathrm{a}$ & $3.92 \pm 1.61 \mathrm{a}$ & $15.83 \pm 5.82 \mathrm{a}$ & $25.78 \pm 4.35 \mathrm{a}$ \\
\hline
\end{tabular}

Note $\square$ Mean values (means $\pm \mathrm{SD}, \mathrm{n}=6$ ) followed by different letters indicate significant difference between landuse types at the $P<0.05$ level. The same below. MC $\square$ moisture content $\square \mathrm{MBC} \square$ micro biomass carbon; MBN: microbiomass nitrogen: SOC: soil organic carbon: TN: total nitrogen; $\mathrm{NH}_{4}{ }^{+}-\mathrm{N}$ : Ammonium nitrogen; $\mathrm{NO}_{3}{ }^{\square}-\mathrm{N}$ : Nitrate nitrogen; TP: total phosphorus; AP: available phosphorus; TK: total potassium; AK: available potassium.

\section{Venn diagram of soil microorganisms in different land-use patterns}

The bacterial Venn diagram of the three land-use patterns is shown in Figure 1A. There were 3,680 soil bacteria OTUs in the three land-use types of grassland, forest and plough; among them, 2,208 OTUs were in the three land-use types, accounting for $60.27 \%$ of all OTUs. The maximum number of grassland soil bacteria OTUs was 3028 , accounting for $82.28 \%$ of the total, and the number of unique OTUs was 207 , accounting for $5.63 \%$ of the total. The lowest number of soil bacteria OTUs was 2888 , accounting for $78.48 \%$ of the total, and the number of specific OTUs was 90 , accounting for $2.45 \%$ of the total. The number of plough soil bacteria OTUs was 3,018 , accounting for $82.01 \%$ of the total, and the number of unique OTUs was 337 , accounting for $9.16 \%$ of the total.

The fungi Venn diagram of the three land-use patterns is shown in Figure 1B. There were 1,819 soil fungal OTUs in the three land-use types of grassland, forest and plough, among which 205 OTUs were in the three land-use types, accounting for $11.26 \%$ of all OTUs. The maximum number of plough soil fungal OTUs was 1042 , accounting for $57.28 \%$ of the total, and the number of unique OTUs was 545 , accounting for $29.96 \%$ of the total. The lowest number of OTUs was 649 , accounting for $35.68 \%$ of the total, and the number of unique OTUs was 192 , accounting for $10.55 \%$ of the total. The number of forest soil fungal OTUs was 745 , accounting for $40.95 \%$ of the total, and the number of unique OTUs was 228 , accounting for $12.53 \%$ of the total.

\section{Effects of land-use patterns on alpha diversity of soil bacteria and fungi}

There was no significant difference between the Shannon index and Simpson index of soil bacteria. However, the soil bacterial Ace and Chao1 indexes of the three land-use patterns were significantly different $(P<0.05)$. Among them, the Ace index showed plough $>$ forest $>$ grassland, and there were significant differences between grassland, forest, and plough $(P<0.05)$. The Chao1 index result was plough $>$ forest $>$ grassland, and the three land-use types had significant differences $(P<0.05)$. The number of soil bacteria OTUs was significantly different and showed plough $>$ forest $>$ grassland.

The soil fungal Shannon index, Simpson index, Ace index, Chao1 index, and OTU index were significantly different (Table 2). The OTU index was ranked plough > forest > grassland; the Shannon diversity index was plough > grassland > forest; the Simpson index was forest > grassland> plough; the Ace index was plough > forest > grassland; and the Chao1 index was plough > forest > grassland. 
Table 2 Diversity index of soil bacterial and fungal communities in different

land use patterns

\begin{tabular}{cccccl}
\hline & Land use types & Shannon & \multicolumn{1}{c}{ Simpson } & \multicolumn{1}{c}{ Ace } & \multicolumn{1}{c}{ Chao1 } \\
\hline Bacterial & Forest & $6.34 \pm 0.19 \mathrm{a}$ & $0.0045 \pm 0.0012 \mathrm{a}$ & $2292.25 \pm 141.12 \mathrm{a}$ & $2284.91 \pm 139.51 \mathrm{ab}$ \\
& Grassland & $6.08 \pm 0.30 \mathrm{a}$ & $0.0077 \pm 0.0041 \mathrm{a}$ & $1977.76 \pm 397.36 \mathrm{~b}$ & $1990.98 \pm 391.46 \mathrm{~b}$ \\
\multirow{3}{*}{ Fungal } & Plough & $6.32 \pm 0.49 \mathrm{a}$ & $0.0126 \pm 0.0199 \mathrm{a}$ & $2401.35 \pm 131.88 \mathrm{a}$ & $2408.77 \pm 140.43 \mathrm{a}$ \\
& Forest & $2.73 \pm 0.48 \mathrm{~b}$ & $0.1506 \pm 0.0639 \mathrm{a}$ & $380.89 \pm 238.18 \mathrm{~b}$ & $358.88 \pm 11.91 \mathrm{~b}$ \\
& Grassland & $3.09 \pm 0.46 \mathrm{~b}$ & $0.1205 \pm 0.0808 \mathrm{a}$ & $242.13 \pm 30.06 \mathrm{c}$ & $111.91 \pm 24.81 \mathrm{c}$ \\
& Plough & $4.04 \pm 0.34 \mathrm{a}$ & $0.0597 \pm 0.0353 \mathrm{~b}$ & $465.72 \pm 39.03 \mathrm{a}$ & $468.18 \pm 23.50 \mathrm{a}$ \\
\hline
\end{tabular}

\section{Effects of land-use patterns on beta diversity of soil bacteria and fungi}

The beta diversity of bacterial and fungal communities in different land-use patterns was measured by the h-cluster and PCoA of the Bray-Curtis distance. The beta diversity of the bacterial community is shown in Figures $2 \mathrm{~A}$ and $2 \mathrm{~B}$, with significant differences between bacterial community structures in different land-use patterns (PERMANOVA: $r=0.43, P<0.01$ ). This result indicates that the differences within samples are not significant, and the differences mainly come from the different samples. Long-term changes in land use will lead to significant changes in bacterial community structure. The beta diversity of fungal communities is shown in Figures $2 \mathrm{C}$ and $2 \mathrm{~B}$, with significant differences between fungal community structures in different land-use patterns (PERMANOVA: $r=0.54, P<0.01$ ). This result indicates that the differences within samples are not significant, and the differences mainly come from the different samples. Long-term changes in land use will lead to significant changes in fungal community structure.

\section{Analysis of soil bacterial and fungal community structure in different land-use patterns}

From the perspective of the overall bacterial community structure, all OTUs belong to 55 bacterial phyla. If the sequence cannot be classified to the known phylum level, the phylum can be uniformly classified into "others". According to the relative abundance of all phylum levels of the three land-use patterns, the dominant bacteria in the samples were Proteobacteria, Acidobacteria and Actinobacteria (Figure 3A). The relative abundance of actinomycetes among the dominant bacteria in the original grassland soil was $30.01 \%$, the relative abundance of Acidobacteria was $29.52 \%$, and the relative abundance of Proteobacteria was $17.57 \%$ (Figure 3B). The dominant phylum in plough soil was Proteobacteria, with a relative abundance of $31.22 \%$; additionally, the relative abundance of Actinomycota was $8.73 \%$, and the relative abundance of Acidobacteria was $21.42 \%$ (Figure 3C). The dominant phylum in forest was Acidobacteria, with a relative abundance of $35.7 \%$; additionally, the relative abundance of Proteobacteria was $20.53 \%$, and the relative abundance of Actinomycota was $15.8 \%$ (Figure 3D).

From the perspective of the overall composition of the fungal community structure, all OTUs belong to 35 bacterial phyla, and the sequences that cannot be classified to a known phylum level are uniformly classified as "others". From the relative abundance of all levels of the three land-use patterns, the dominant phyla in the sample were Ascomycota, Basidiomycota, and Zygomycota (Figure 4A). The 
relative abundance of Ascomycota is grassland was $62.74 \%$, making it the dominant soil fungi; additionally, the relative abundance of Basidiomycota was $2.60 \%$, and the relative abundance of Zygomycota was $0.86 \%$ (Figure 4B). After the grassland was converted to plough, the dominant mycoplasma was still Ascomycota, with an abundance of $46.63 \%$, the abundance of Basidiomycota was $11.87 \%$, and the abundance of Zygomycota was $7.28 \%$ (Figure $4 \mathrm{C}$ ). The dominant phylum of the forest was Basidiomycota, with an abundance of $76.68 \%$; it was followed by Ascomycota, with an abundance of $15.90 \%$, and Zygomycota, with an abundance of $1.18 \%$ (Figure 4D).

One-way ANOVA and two-sample T-test method were used to analyse the difference in abundance of bacterial community gates in different land-use patterns. A total of 7 gates had significant differences in the three land-use patterns (Figure 5A). These included Acidobacteria $(P<0.05)$, Actinobacteria $(P<0.001)$, Gemmatimonadetes $(P<0.05)$, Bacteroidetes $(P<0.001)$, Planctomycete $(P<0.001)$, unclassified_k_norank $(P<0.05)$, and Latescibacteria $(P<0.01)$. There were significant differences between the 4 gates of forest and grassland (Figure 5B), mainly in Actinobacteria $(P<0.001)$, Bacteroidetes $(P<0.001)$, unclassified_k_norank $(P<0.05)$, and Latescibacteria $(P<0.01)$. There were significant differences between the 9 forest and plough gates (Figure 5C), mainly in Acidobacteria $(P<0.05)$, Proteobacteria $(P<0.05)$, Chloroflexi $(P<0.05)$, Gemmatimonadetes $(P<0.05)$, Acteroidetes $(P<0.001)$, Saccharibacteria $(P<0.05)$, Planctomycetes $(P<0.001)$, Parcubacteria $(P<0.05)$, and Latescibacteria $(P<0.001)$. There were significant differences between 7 gates in grassland and plough (Figure 5D), including Proteobacteria $(P<0.05)$, Actinobacteria $(P<0.001)$, Gemmatimonadetes $(P<0.05)$, Bacteroidetes $(P<0.001)$, Saccharibacteria $(P<0.05)$, Planctomycetes $(P<0.001)$, and Parcubacteria $(P<0.05)$.

Based on the difference in the level abundance of the fungal community gates in the three land-use patterns (Figure 6), there were 6 gates with significant differences in the three land-use patterns: Ascomycota $(P<0.001)$, Basidiomycota $(P<0.001)$, Zygomycota $(P<0.01)$, Glomeromycota $(P<0.01)$, and Chytridiomycota $(P<0.05)$. There were significant differences between the two gates of plough and grassland (Figure 6B), mainly in Basidiomycota $(P<0.05)$ and Zygomycota $(P<0.01)$. There were significant differences between the four gates of forest and plough (Figure 6C), mainly in Basidiomycota $(P<0.001)$, Ascomycota $(P<0.01)$, Zygomycota $(P<0.01)$, and Glomeromycota $(P<0.05)$. There were significant differences between the 7 gates in grassland and forest (Figure 6D), mainly in Basidiomycota $(P<0.001)$, Ascomycota $(P<0.001)$, and Glomeromycota $(P<0.05)$.

From the differences in the composition of the bacterial communities in the three land-use patterns, there were a total of 9 classifications that had significant differences among the three land-use patterns (Figure 7A): c_Acidobacteria, $g \_R B 41, \mathrm{f} \_$Nitrosomonadaceae, o_Acidimicrobiales, g_Sphingomonas, O_Gaiellales, C_Actinobacteria, f_JG34-KF-161, and c_KD4-96. There were significant differences between the four classifications of forest and grassland (Figure 7B): C_Acidobacteria, O_Acidimicrobiales, $\mathrm{f} \_$Nitrosomonadaceae, and $\mathrm{f} \_$Elev-16S-1332. There were significant differences between the 8 classifications of forest and plough (Figure 7C): C_Acidobacteria, g_RB41, g_Sphingomonas, f_JG34-KF-161, o_Acidimicrobiales, C_Gemmatimonadetes, C_Actinobacteria, and C_KD4-96. There were significant differences between the 9 classifications of grassland and plough 
(Figure 7D): g_RB41, f_Gemmatimonadacese, o_Acidimicrobiales, g_Sphingomonas, f_Nitrosomonadaceae, o__Gaiellales, C_Actinobacteria, f_JG34-KF-161, and p_Saccharibacteria.

From the difference in the abundance of the classification of fungal communities in the three land-use patterns, a total of five classifications had significant differences (Figure 8A): k_Fungi, Inocybe, p_Ascomycota, Mortierella, and Guehomyces. There were significant differences between 15 classifications of forest and grassland (Figure 8B): Inocybe, p_Ascomycota, k_Fungi, o_Geoglosssales, Cortinarius, f_Thelephraceae, Rhizoplagus, Ilyonectria, Myrothecium, o_Sebacineles, o_Microascales, o_SoCCAriales, Paraphoma, Ramicandelaber, and Apodus. There were significant differences between 15 classifications of forest and plough (Figure 8C): Inocybe, k_Fungi, Morticrella, Chaetomium, f_Lasioshaenaceae, Fusarium, Guehomyces, Cortinatius, Microdochium, o_Lpeosporales, o_Lpeosporales, f_Davidellaceae, f_Glomeraceae, Cryptococcus, and Schizothecium. There were significant differences between the 15 classifications of grassland and plough (Figure 8D): p_Ascomycota, Mortierella, Chaetomium, f_Lasioshaenaceae, Guehomyces, o_Geoglossales, o_Lpeosporales, o_Lpeosporales, Microdochium, Geopora, Cryptococcus, Schizothecium, Stachypotrys, f_Thelephraceae, and Talaromyces.

\section{Functions of soil bacterial and fungal communities in different land-use modes}

Using the PICRUSt function prediction software to analyse the soil bacterial community functions in different land-use patterns, it can be seen from Figure 9A that the bacterial community functions are mainly amino acid transport and metabolism; energy production and conversion; signal transduction mechanisms; cell wall/membrane biogenesis; transcription; carbohydrate transport and metabolism; inorganic ion transport and metabolism; translation, ribosomal structure and biogenesis; lipid transport and metabolism; posttranslational modification, protein turnover; coenzyme transport and metabolism; secondary metabolite biosynthesis, transport and catabolism; nucleotide transport and metabolism; defence mechanisms; cell cycle control, cell division, chromosome partitioning; RNA processing and modification; and chromatin structure and dynamics. It can be seen from Table 3 that except for the three functions of intracellular trafficking, secretion, and vesicular transport, cytoskeleton, and extracellular structures, there were no significant differences in the other functions.

Table 3 Functional categories of soil bacterial communities in different land uses patterns 
Functional categories

Amino acid transport and metabolism

Energy production and conversion

Signal transduction mechanisms

Cell wall/membrane/envelope

biogenesis

Transcription

Carbohydrate transport and metabolism

Replication, recombination and repair

Inorganic ion transport and metabolism

Translation, ribosomal structure and

biogenesis

Lipid transport and metabolism

Posttranslational modification, protein

turnover

Coenzyme transport and metabolism

Secondary metabolites biosynthesis,

transport and catabolism

Nucleotide transport and metabolism

Intracellular trafficking, secretion, and

vesicular transport

Defense mechanisms

Cell motility

Cell cycle control, cell division,

chromosome partitioning

RNA processing and modification

Chromatin structure and dynamics

Cytoskeleton

Extracellular structures
Grassland

Forest

Grassland

2156599.2 $\pm 108447.22120358 .2 \pm 116315.21748427 .5 \pm 205193.50 .000^{* *}$ $1928593.2 \pm 107958.51908954 .6 \pm 90947.3 \quad 1528709.8 \pm 219359.10 .000 * *$ $1803505.5 \pm 137977.51923574 .2 \pm 68798.7 \quad 1535812.2 \pm 264067.10 .005^{* *}$

1729648.6 $\pm 169565.41852972 .3 \pm 88768.4 \quad 1548832.8 \pm 227847.30 .025^{* *}$

1779757.8 $\pm 133546.21641553 .8 \pm 94778.1 \quad 1340401.2 \pm 140126.10 .000 * *$

$1595887.6 \pm 117559.21558833 .6 \pm 67370.7 \quad 1255254.2 \pm 117630.20 .000 * *$

$1386877.8 \pm 95824.8 \quad 1462371.2 \pm 37611.2 \quad 1212317.6 \pm 105834.30 .000 * *$

$1319226.6 \pm 48655.41335140 .6 \pm 54643.4 \quad 1186993.3 \pm 131597.2$ 0.019**

$1301982 \pm 66153.5 \quad 1344664.6 \pm 47191.1 \quad 1160419.5 \pm 100831.40 .002 * *$

$1206223.8 \pm 72042.6 \quad 1101692.2 \pm 73651.1 \quad 915392.6 \pm 157000.6 \quad 0.001 * *$

$1050106.8 \pm 77086.9 \quad 1093560.5 \pm 29778.8 \quad 915481 \pm 137360.9 \quad 0.012 * *$

1073806.2 $\pm 62419.2 \quad 1086196.8 \pm 43176.4 \quad 869490.5 \pm 116424.1 \quad 0.000 * *$

$689507.2 \pm 54717.2 \quad 604978.6 \pm 45849.2 \quad 515565 \pm 104471.65 \quad 0.003 * *$

$603415.3 \pm 30170.3 \quad 606498.6 \pm 23482.8 \quad 508177.6 \pm 39370.8 \quad 0.000 * *$

$\begin{array}{llll}537396 \pm 63154.4 & 596019.2 \pm 41039.5 & 501255 \pm 90025.5 & 0.081\end{array}$

$\begin{array}{lllll}568486 \pm 63298.95 & 587746.8 \pm 28131.8 & 460686.3 \pm 52408.5 & 0.001 * *\end{array}$

$\begin{array}{lllll}354935.2 \pm 50017.4 & 418557.2 \pm 34696.3 & 349513 \pm 63870.7 & 0.060\end{array}$

$248219.3 \pm 8540.1 \quad 256330.6 \pm 10094.2 \quad 221646.2 \pm 20168.9 \quad 0.002 * *$

$15313.8 \pm 1803.7 \quad 14234.6 \pm 1124.5 \quad 10122.8 \pm 2365.9 \quad 0.000 * *$

$12625.6 \pm 1368.4 \quad 13349 \pm 445.5 \quad 10521 \pm 2049.6 \quad 0.011 * *$

$\begin{array}{llll}4539.8 \pm 903.2 & 5484.8 \pm 723.7 & 5335.5 \pm 1080.1 & 0.191\end{array}$

$17 \pm 11.5 \quad 12.5 \pm 6.1 \quad 19.1 \pm 12.7$

0.584

Note $\square$ Mean values (means $\pm \mathrm{SD}, \mathrm{n}=6$ ), Significant levels are indicated at the $* P<0.05 ; * * P<0.01$.

Using FUNGuild software to analyse soil fungal community functions under different land-use patterns, it can be seen from Figure 9B that the fungal community functions in the three land patterns are:

ectomycorrhizal; animal pathogen; endophyte; dung saprotroph; plant pathogen; arbuscular mycorrhizal;

fungal parasite; endomycorrhizal-plant pathogen; bryophyte parasite-ectomycorrhizal; and

clavicipitaceous endophyte-plant pathogen. As seen from Table 4, there are significant differences in the

functions of the five communities in terms of ectomycorrhizal, animal pathogen, endophyte, dung saprotroph, and fungal parasite. After the grassland was transformed into forest, the ectomycorrhizal functional group increased significantly. After the grassland was transformed into plough, the functional groups of animal pathogens, endoparasites, and faecal saprophytic organisms increased significantly.

Table 4 Functional categories of soil fungal communities in different land use patterns 


\begin{tabular}{llllc}
\hline \multicolumn{1}{c}{ Functional categories } & Grassland & Forest & Grassland & $\mathrm{p}$ \\
\hline Ectomycorrhizal & $46.3 \pm 52.8$ & $25381.6 \pm 5074.5647 .5 \pm 271.8$ & $0.000^{* *}$ \\
Animal Pathogen & $414.6 \pm 286.6337 .5 \pm 281.2$ & $3374.1 \pm 2621.5$ & $0.005^{* *}$ \\
\hline Endophyte & $430.6 \pm 447.8425 .6 \pm 287.2$ & $2532.5 \pm 772.1$ & $0.000^{* *}$ \\
\hline Dung Saprotroph & $56.3 \pm 92.4$ & $28 \pm 20.1$ & $3004.6 \pm 2592.9$ & $0.005^{* *}$ \\
\hline Plant Pathogen & $320.5 \pm 279.370 .3 \pm 40.2$ & $1822.1 \pm 2106.10 .054$ \\
\hline Arbuscular Mycorrhizal & $603.8 \pm 622.720 .33 \pm 31.15$ & $725.8 \pm 708.1$ & 0.088 \\
\hline Fungal Parasite & $209.6 \pm 312.453 .1 \pm 53.6$ & $378.8 \pm 148.1$ & $0.043^{*}$ \\
\hline Endomycorrhizal-Plant Pathogen & $271 \pm 387.9$ & $40.8 \pm 30.2$ & $27 \pm 14.8$ & 0.142 \\
\hline Bryophyte Parasite-Ectomycorrhizal & $6.5 \pm 9.4$ & $1 \pm 1.09$ & $0 \pm 0$ & 0.122 \\
\hline Clavicipitaceous Endophyte-Plant Pathogen $0 \pm 0$ & $0 \pm 0$ & $1.66 \pm 4.8$ & 0.391 \\
\hline
\end{tabular}

\section{Redundancy analysis of soil bacterial and fungal communities and physicochemical properties in different land-use patterns}

The relationship between soil physical and chemical properties and the community composition of bacteria and fungi at the OTU level was analysed using CCA, and the results are shown in Figure 10. The first sequence axis of bacteria explained $29.61 \%$ of all information, and the second sequence axis explained $21.07 \%$ of all information. $\mathrm{pH}$ is the main factor affecting the composition of grassland bacterial communities, and soil nutrients such as $\mathrm{O}_{3}{ }^{-} \mathrm{N}, \mathrm{TP}, \mathrm{AP}$, and $\mathrm{NH}_{4}{ }^{+}-\mathrm{N}$ are the main factors affecting the composition of bacterial communities in forests and ploughs. The first sequence axis of fungi explained $15.93 \%$ of all information, and the second sequence axis of fungi explained $14.41 \%$ of all information. $\mathrm{pH}$ is the main factor affecting the composition of grassland fungal communities, $\mathrm{MC}$ is the main factor affecting the composition of forest fungal communities, and $\mathrm{NO}_{3}{ }^{-} \mathrm{N}, \mathrm{TP}$ and $\mathrm{AP}$ are the main factors affecting the composition of plough fungal communities.

\section{Discussion}

\section{Impact of land use on soil bacterial and fungal community diversity}

The results of this study show that different land-use patterns significantly change the soil bacterial Ace and Chao1 indexes. Compared with grasslands, the soil bacterial richness indexes of plough and forests increased significantly, but the Shannon and Simpson indexes did not change (Table 2), indicating that after the grassland was changed to forest and plough, the soil bacterial community richness increased significantly, while its uniformity did not change. Compared with the bacteria, the Shannon, Simpson, Ace, and Chao 1 indexes of the three land-use soil fungi were significantly different. After the grassland was converted to forest and plough, the diversity of the soil fungal community increased significantly (Table 2). This result may be due to the increase in soil fungal diversity after conversion to forest due to abundant litter. This result is consistent with previous research, where afforestation often stimulates the growth of soil fungal communities ${ }^{[15]}$, while soil bacteria appear to be less sensitive to land use ${ }^{[16,17]}$. According to research reports, bacterial community structure, diversity and biomass are more resistant 
than those of fungi ${ }^{[18]}$. This difference may be because bacteria can produce a wider range of metabolites to adapt to the new environment. In contrast, fungi depend to a large extent on the presence of their hosts ${ }^{[19]}$, so the structure and diversity of fungal communities have more dramatic changes based on land use.

\section{Effects of land-use patterns on soil bacterial community composition}

At the gate level, the dominant phyla in the three types of soil are Proteobacteria, Acidobacteria, and Actinomyces, which can account for more than $80 \%$ of the total bacterial community in each soil sample. The community structure results are consistent ${ }^{[20,21]}$. However, this study also found that when the grassland was changed to forest and plough, the abundance of its dominant bacteria changed significantly.

This study found that the relative abundance of grassland soil actinomycetes was the highest. After conversion to forest and plough, the soil actinomycete content decreased significantly. Several studies have shown that actinomycetes are the most widely distributed in the four herbaceous vegetation soils, and their relative abundance is significantly higher than that of forests and ploughs; actinomycetes are the dominant mycophytes in grassland soils ${ }^{[22,23]}$. Actinomyces can degrade cellulose and chitin, which is the main source of the soil nutrient supply. It can decompose more difficult-to-decompose organic carbon by infiltrating its hyphae into large plant tissues, and the spores produced can resist unfavourable external environmental conditions and are considered to be dominant in harsh and stressful soil conditions $^{[24]}$. The relative abundance of Proteobacteria was lowest in grassland soils. Liu et al. ${ }^{[25]}$ found that the relative abundance of Proteobacteria may be controlled by the difference in soil nutrients. Soil total phosphorus is the main factor affecting the distribution of Proteobacteria, with an interpretation rate as high as $85.3 \%$. Other studies have found that Proteobacteria are relatively abundant in nutrient-rich soils but also relatively abundant in soil that are nutritionally poor ${ }^{[26]}$. The relative abundance of Planctomycetes was highest in grasslands. Fei et al. ${ }^{[27]}$ found that there was a significant positive correlation between floating mould and soil total nitrogen content. The total nitrogen content of grassland was the highest among the three land patterns in this study, making the relative abundance of floating mould the highest in grassland soil. Fu et al. ${ }^{[27]}$ found that the floating fungus phylum occupied a certain proportion in the bacterial community in the green space of the fifth ring road in Beijing, reflecting the alkaline and nutrient-poor soils in the study area, and the soil biological activity was low.

The results of this study indicate that the relative abundance of Acidobacteria was the highest after the grassland was transformed into forest land, and it became the dominant bacteria in soil. Acidobacteria can grow on the medium using plant polymer as a substrate, indicating that Acidobacteria play an important role in the degradation of plant residues and degradation of forest litter ${ }^{[29]}$. Pankratov et al. ${ }^{[30]}$ found that although the Acidobacteria degradation function is not as good as other known cellulosedegrading bacteria, it has strong resistance to stress and can survive in cold northern soils, which plays an important role in cellulose degradation under these conditions. Based on this study, there is less litter 
content in the grassland and plough patterns, and the forest litter content is significantly higher than that in forest land and grassland. Therefore, the content of insoluble matter in litter is also high. As a result, they are more susceptible to litter composition, making Acidobacteria more abundant in forests. Maestre et al. ${ }^{[31]}$ found, in Northeast China, that the abundance of Acidobacteria decreased in the order of the soils of Yanji, Siping, and Tongliao, which may be the result of increased soil drought. In this study, the water content was the highest in forest, which may also be the cause of the increase in soil acid bacilli. Therefore, it can be concluded that the abundance of Acidobacteria is mainly related to the composition and content of litter, which is considered to be related to soil moisture content.

After the grassland was transformed into plough, the soil actinomycete content decreased significantly. Clegg et al. ${ }^{[32]}$ found that the addition of inorganic nitrogen reduced the abundance of actinomycetes compared with the non-fertilized grassland soil. In this study, due to the application of chemical fertilizers throughout the year, the soil $\mathrm{NO}_{3}-\mathrm{N}$ content increased, the soil structure changed, and the relative abundance of soil actinomycetes decreased. Therefore, it can be concluded that the main reason for the decrease in the relative abundance of actinomycetes after grassland conversion to plough may be due to the increase in soil nutrient content in plough. After the grassland was transformed into plough, the relative abundance of Proteobacteria significantly increased and became the dominant Mycoplasma in plough. Numerous studies have shown that the relative abundance of Proteobacteria in plough soils makes it the dominant phylum ${ }^{[33,34]}$. When substrates with high resource availability exist in the soil, Proteobacteria are more abundant in the soil ${ }^{[35]}$. Li et al. ${ }^{[36]}$ found that Proteobacteria was the main group of saline-alkali soils. The soil in this study was alkaline, and it was also verified that Proteobacteria was the main dominant community in alkaline soil. Michael et al. ${ }^{[37]}$ found that a dominant phylum was transformed from an actinomycete to a proteobacterium after conversion from a pasture to a plough. Pascault et al. ${ }^{[38]}$ found that Proteobacteria had the fastest decomposition rate of beans in plough, indicating that Proteobacteria had a good effect on the degradation of crop residues. Plough soil Proteobacteria were the most abundant in this study, which shows that it plays an important role in the crop decomposition process. After the grassland was converted to plough, Gemmatimonadetes increased. Several studies have shown that Bacillus has a relatively high abundance in plough soils ${ }^{[39]}$. Gemmatimonadetes is an alkalophilic microorganism and can produce spores, which can resist dehydration and adapt to drought and extreme environmental conditions. Some Gemmatimonadetes species have strong nitrogen-fixing effects and play an important role in the biological control of the production and release of plant hormones and soil-derived plant pathogens (such as fungi) ${ }^{[40,41]}$. Mahoney et al. ${ }^{[42]}$ found that winter wheat soil bacterial communities were rich in Gemmatimonadetes. Monreal et al. ${ }^{[43]}$ found rich Gemmatimonadetes communities in rapeseed agricultural soils in Ottawa, Canada. This result shows that Gemmatimonadetes has a higher abundance in plough soil. Plough is an artificial ecosystem with a monoculture. Due to the effect of external nitrogen application, the available nitrogen content in the soil is high. Because Gemmatimonadetes has a strong nitrogen-fixing capacity, its content is highest in ploughs. After the grassland was converted to plough, Bacteroidetes increased. Bacteroidetes are mainly anaerobic or facultative anaerobic bacteria and can be found in a variety of 
habitats, including soil, sediment and seawater. Li et al. ${ }^{[44]}$ studied the black soil plough in Northeast China and found that Bacteroidetes were the dominant bacteria in the soil. These flora were found to be the most common flora in plough and forest soil. Turner et al. ${ }^{[45]}$ and Donn et al. ${ }^{[46]}$ also found that the abundance of Bacteroidetes was higher in the field soils of wheat and pea. Gkarmiri et al. ${ }^{[4]}$ and Xiao et al. ${ }^{[48]}$ found a large number of Bacteroidetes in soils in rapeseed fields, alfalfa and other plants. Bergkemper et al. ${ }^{[49]}$ found that the relative abundance of Bacteroidetes was positively related to available phosphorus, and available phosphorus may be one of the important factors affecting the bacterial community. In this study, due to the application of chemical fertilizers to the plough land, the available phosphorus content was the highest, and the relative abundance of Bacteroidetes increased in the plough soil.

\section{Effects of land-use patterns on the composition of soil fungal communities}

Among the three land-use patterns, the soil fungal groups were mainly Ascomycota, Basidiomycota, and Zygomycota. Ascomycota was the dominant phylum in grassland soil. Cao Hongyu et al. ${ }^{[50]}$ also found that the grassland soil fungus Ascomycota accounted for the highest abundance, which was mainly due to the faster evolution rate of Ascomycota, drought resistance and radiation resistance, suitability for bare sand with a low vegetation canopy and harsh living environments such as land and grassland ${ }^{[51]}$. Zhang et al. ${ }^{[52]}$ found that Ascomycota was the dominant bacteria in the most primitive grassland, and its dominant orders are mainly Hypocreales and SoCCAriales. Its abundance in forestland decreases significantly with increasing age. Most SoCCAriales are saprophytic, usually found on faeces or rotten plants. In our study area, animal dung was found in grazing grasslands, and animal and human dung in plough lands are common fertilizers. Therefore, Ascomycetes become the dominant bacteria in grasslands and ploughs.

After the grassland was transformed into forestland, Basidiomycota increased significantly in the forestland and became the dominant phylum in the soil. This result is consistent with previous studies. After 29 years of pine planting in the wasteland, the relative abundance of Basidiomycota increased from $10.9 \%$ to $68.7 \%{ }^{[24]}$. During the fungal succession of the Damma glacier forefield in central Switzerland, it was found that the community dominated by Ascomycota became a community dominated by Basidiomycota ${ }^{[53]}$. Basidiomycota are the dominant ectomycorrhizal species, which are more abundant in oak and oak forests. The genera Mycelium and Lactobacillus in Basidiomycota are common mycorrhizal fungi in forest soils, which can be symbiotic with Pinus sylvestris var. Mongolica and thus account for a large proportion of soil fungi ${ }^{[54]}$. Other Basidiomycota flora, especially white rot fungi, can breakdown litter with high lignin and aromatic substrates. However, only a small group of fungal groups have the ability to secrete enzymes that catalyse the degradation of complex macromolecules such as lignin ${ }^{[55]}$, and they are largely confined to the Agaricus species in Basidiomycota ${ }^{[56]}$. In this study, litterfall increased significantly after grassland afforestation, requiring more decomposing bacteria, which is also the reason for the increase in soil Basidiomycota. 
After the grassland was transformed into plough land, the dominant fungal phylum was still Ascomycetes, but Zygomycota significantly increased. Part of Zygomycota is a saprophytic fungus that mainly decomposes plant litter and changes soil chemical properties. Angela et al. ${ }^{[6]}$ found that the majority of Zygomycota in the genus Zygomycota were predominant in Colombia, which is consistent with this study. Qian et al. ${ }^{[58]}$ found that the relative abundance of soil fungal Zygomycota increased after grass growing in apple orchards, indicating that grass would affect the relative abundance of soil Zygophyta. It will convert matter to humus and provide a carbon source to increase soil organic carbon. Zygomycota are mostly saprophytic, which can make good use of the saprophytic environment. Zygomycota are also pathogenic bacteria, which can be parasitic when plants are weak, easily causing postpartum diseases. The study found that the relative abundance of Zygomycota had a significant positive correlation with the soil nitrate nitrogen content and with the increase in the soil nitrate nitrogen content. The highest nitrate nitrogen content in ploughs in this study may cause an increase in Zygomycota. Li et al. ${ }^{[59]}$ found that the relative abundance of Zygomycota in apple field and corn field was greater than that in an intercropped field, and the relative abundance of soil fungi in different categories and subgenera was also different, indicating that, due to the differences in crop roots, residues, secretions, and crop management and maintenance, the method affects the physical and chemical properties of the soil, and then changes the microbial species composition and its structure. Although the species composition of soil bacterial communities is similar between different land-use patterns, the relative abundance of soil bacterial phyla and genera may be different because of different plant patterns and differences in the form and content of nutrients provided to the soi[ ${ }^{[60,61]}$.

\section{Effects of land-use patterns on functional changes in soil bacterial and fungal communities}

After land-use change, the function of the inherent bacterial community changed due to differences in the aboveground vegetation community, surface litter composition, decomposition rate, and degree of interference from human activities. In this study, it was found that except for a small number of three functions, including intracellular trafficking, secretion, and vesicular transport, cytoskeleton, and extracellular structures, there were significant changes in the functions of other bacterial communities (Table 3). This result shows that the change in land-use patterns has a significant effect on the function of surface soil bacterial communities. Zhang et al. ${ }^{[62]}$ found that during the transition from secondary forest to larch plantation, due to soil acidification and a reduction in effective nutrient content, land-use patterns had a greater impact on soil bacterial communities. We found that after a long-term change in the original grassland, the bacterial function in the $0-20 \mathrm{~cm}$ soil changed, and the bacterial function of the plough decreased compared with that of the grassland and forest (Table 3). The nutrient conversion and return and the litter quality and quantity of forest and grassland were higher than those of plough, which was consistent with the research results of many scholars ${ }^{[63,64]}$.

After land-use changes, the functional groups of fungal communities changed significantly. The grassland was transformed into forest Inocybe. The abundance of Inocybe significantly increased. The species belonged to Basidiomycota and was an ECM fungi. ECM fungi are reported to be most widely 
distributed in trees in northern temperate regions ${ }^{[65]}$. Because ECM fungi are strongly affected by the host, their richness is positively related to the proportion of ECM plants and species richness. In northern temperate deciduous forests, ECM fungi accounted for $34.1 \%$ of all taxonomic units, while in grasslands, they accounted for only $11.9 \%$, which reflected the lack of host plants in grassland ecosystems ${ }^{[66]}$. After the grassland was converted to plough, the relative abundance of Mortierella, Chaetomium and Microdochium increased significantly, and they were common saprophytic fungi in soil. Liang et al. ${ }^{[67]}$ studied a vineyard and found that the most abundant fungal genera included Mortierella, Chaetomium and Microdochium, which may be considered to play a key role in planting soil. $\mathrm{Li}^{[68]}$ found that the inoculation of corn with Mortierella significantly increased soil nutrient transformation, increased the content of indole acetic acid and abscisic acid in corn roots, and increased the biomass of corn seedlings. In addition, it had the ability to decompose cellulose, hemicellulose and lignin, increase carbon nutrients, increase soil organic matter and nutrient content, and dissolve phosphorus in the soil. Therefore, it has been recognized as a beneficial soil microorganism by the genus Sporella. Most microsporum fungi are saprophytic, some species are parasitic or symbiotic, and most are phytopathogenic ${ }^{[69]}$. Therefore, the fungal functions of plough soils are mainly saprophytic, parasitic, animal pathogens, and mycorrhizal.

\section{Effects of soil physical and chemical properties on soil microbial community composition}

Land-use and management patterns will change the type of vegetation on the ground and then affect the physical and chemical properties of the soil ${ }^{[70,71]}$. Changes in soil physical and chemical properties will affect the structure and composition of soil microbial communities. Consistent with most other studies, $\mathrm{pH}$ is an important factor affecting soil microbial community structure. Barka et al. ${ }^{[72]}$ found that there was a significant positive correlation between Actinomycetes and soil $\mathrm{pH}$. Actinomycetes grew healthily in soils with a neutral $\mathrm{pH}$ and grew fastest between $\mathrm{pH} 6$ and 9. Rousk et al. ${ }^{[3]}$ found that both bacterial and fungal communities were affected by soil $\mathrm{pH}$, but bacterial communities were more affected by $\mathrm{pH}$ than were fungal communities, which may be due to the relatively narrow optimal $\mathrm{pH}$ range for bacterial growth, while the $\mathrm{pH}$ range for fungal growth is very wide. Although soil $\mathrm{pH}$ has a direct impact on microbial community structure, soil pH can also indirectly change microbial communities through other variables, such as nutrient utilization and organic carbon content.

As an indispensable source of energy and nutrients for microorganisms, SOC plays an important role in shaping the microbial community and significantly changes the proportion of bacteria and fungi in the soil ${ }^{[74]}$. However, the SOC content in this study may not have caused changes in soil microbial communities. In this study, $\mathrm{NO}_{3}{ }^{-}-\mathrm{N}$ was the most important factor affecting the soil bacterial and fungal communities (Figure 10). Nitrogen restrictions are common in most terrestrial ecosystems and often lead

to fierce competition between microorganisms and plants ${ }^{[75]}$. With the increase in nitrogen availability, the taxonomic and functional characteristics of soil microbial communities change, including the decrease in relative abundance of mycorrhizal fungi and the slow growth of bacterial groups. Due to the low soil nitrogen content and low litter mass in forestland, fungi appear to be the main decomposers of complex 
litter and soil organic matter and have largely affected related bacterial communities and their activities $^{[76]}$. Soil moisture is also an important limiting factor that strongly affects soil microbial communities $^{[77]}$. In this study, MC plays a key role in soil fungal diversity. Not only can it protect soil organic matter from decomposition and leaching by combining with aggregates, it can also provide a larger surface area for the growth of soil microorganisms ${ }^{[78]}$.

In this study, the TP and AP contents of plough and forestland were significantly higher than those of grassland. The reason may be that the interception of rainwater by the forest canopy makes the surface runoff smaller, the soil surface organic matter and mineral nutrients are retained, and the loss is less. The artificial fertilization in the plough compensates for the nutrients in the soil. Other studies have shown that under eutrophic conditions, the limiting effect of phosphorus on the original microbial community has been greatly reduced, and the metabolic activity of microorganisms has changed, which may change the species composition of microorganisms ${ }^{[79]}$. However, the grassland is not supplemented with external nutrients, and the growth of vegetation has absorbed phosphorus in the soil, which ultimately results in lower total phosphorus and available phosphorus in the soil. He et al. ${ }^{[80]}$ found that $\mathrm{P}$ is the most critical contributor to differences in fungal communities, and phosphorus in forestland is usually less than that in managed ecosystems due to fertilization. Therefore, although the exact mechanism is not yet clear, $\mathrm{P}$ may be an important driving force for the construction of soil fungal communities across land-use types.

\section{Conclusions}

Our research results show that there is no significant difference in soil bacterial community diversity and fungal community diversity after grassland changes to forestland. The dominant bacterial phylum changed from Actinobacteria to Acidobacteria, and the dominant fungal phylum changed from Ascomycetes to Basidiomycetes. The ECM functional group increased significantly. After the grassland was changed to plough, there was no significant difference in the diversity of soil bacterial communities, and the diversity of fungal communities increased significantly. The dominant bacterial phylum changed from Actinomycetes to Proteobacteria, and the dominant fungal phylum was Ascomycota. The functional groups of pathogens and parasites increased significantly. Soil pH, MC, NO3-N, TP, AP and other soil factors are important factors affecting the composition of microbial communities. In the soil of this study area, the composition of bacterial communities is mainly driven by changes in $\mathrm{pH}$ and soil texture, and the composition of fungal communities is most closely related to changes in soil nutrient utilization. Changes in land-use patterns have an effect on the structure and diversity of microbial communities by changing the physical and chemical properties of the soil.

\section{Methods}

\section{Overview of research plots}

The study site was located in the Meiris District $\left(123^{\circ} 35^{\prime} \mathrm{E}, 47^{\circ} 31^{\prime} \mathrm{N}\right)$ of Qiqihar City, western Heilongjiang Province, with an average elevation of $146 \mathrm{~m}$. It belongs to a moderate-temperate continental monsoon 
climate, with dry and windy springs, hot and rainy summers, and cold winters. It has less snow, an average temperature of $2.3^{\circ} \mathrm{C}$, and an average rainfall of $454 \mathrm{~mm}$. The freezing period is in early November, and the thawing period is in early May. The three land-use patterns selected in this area are grassland, with an area of approximately $800 \mathrm{hm}^{2}$, and the vegetation is mainly Leymus chinensis (Trin.) Tzvel, and Stipa Baicalensis Roshev. plough, which was cultivated on the grassland 20 years ago, with an area of approximately $600 \mathrm{hm}^{2}$. The main crops are corn, which is mechanically ploughed once a year. Stanley corn compound fertilizer $\left(\mathrm{N}+\mathrm{P}_{2} \mathrm{O}_{5}+\mathrm{K}_{2} \mathrm{O} \geqq 40 \%\right)$ is applied on a per acre basis in spring at $35 \mathrm{~kg}$, and topdressing is at $15 \mathrm{~kg}$ per acre in mid-June. Forest, with an area of approximately $500 \mathrm{hm}^{2}$, is a poplar artificial pure forest that was planted on grassland 20 years ago as a research plot. The plants used in the study were formally identified by Song Fuqiang, and documentary specimens of this material have been stored in the open herbarium.

\section{Sample collection}

In August 2018, 6 standard $50 \mathrm{~m} \times 50 \mathrm{~m}$ plots were selected from three different land-use patterns in grassland, plough, and forest land. Five-point mixed sampling was used to collect soil samples from a depth of $0-20 \mathrm{~cm}$. After passing through a 2-mm sieve, a portion of the sample was placed in a $15 \mathrm{~mL}$ centrifuge tube, stored in liquid nitrogen, transferred to the laboratory and stored in a $-80^{\circ} \mathrm{C}$ refrigerator for DNA extraction and microbial analysis. The remaining soil samples were used to determine the physical and chemical properties of the soil after air-drying.

\section{Physical and chemical analyses}

Determination of soil moisture content (MC): Place the fresh soil samples into the aluminium box, place the lid on the aluminium basin, and place it in the oven that has been preheated to $105^{\circ} \mathrm{C} \pm 2{ }^{\circ} \mathrm{C}$. Bake in a constant-temperature drying oven for $8 \mathrm{~h}$, take out the sample and make the weighing calculation. The soil $\mathrm{pH}$ was measured at a soil/water ratio of 1:2.5. Soil organic matter (SOC): The soil organic carbon content was determined by the vario TOC instrument produced by the German Elementar company. Total nitrogen (TN): Weigh $0.25 \mathrm{~g}$ of soil sample through a $0.149-\mathrm{mm}$ sieve, add $2 \mathrm{~g}$ of zinc sulphate and copper sulphate mixed accelerator and $5 \mathrm{~mL}$ of concentrated $\mathrm{H}_{2} \mathrm{SO}_{4}$ for digestion. After digestion and constant volume filtration, measure with a continuous flow analyser. Nitrate nitrogen $\left(\mathrm{NO}_{3}{ }^{-} \mathrm{N}\right)$ and ammonium nitrogen $\left(\mathrm{NH}_{4}{ }^{+}-\mathrm{N}\right)$ : Weigh $6 \mathrm{~g}$ of air-dried soil, add $10 \mathrm{~mL}$ of $1 \mathrm{~mol} \cdot \mathrm{L}^{-1}$ potassium chloride solution, shake for $1 \mathrm{~h}$, filter, and measure with a continuous flow analyser. Total phosphorus (TP): the sulfuric acid-perchloric acid solution-molybdenum antimony colorimetric method was used. Available phosphorus (AP): $0.5 \mathrm{~mol} \cdot \mathrm{L}^{-1}$ sodium bicarbonate extraction-molybdenum antimony colorimetric determination was used. Total potassium (TK) and available potassium (AK) were determined by atomic absorption spectrometry.

\section{DNA collection and high-throughput sequencing}


Genomic DNA was isolated from $0.5 \mathrm{~g}$ of each pooled soil sample from each sample plot $(n=18)$ with the PowerSoil DNA Isolation Kit per the manufacturer's instructions. The extracts of three technical repeats were mixed into a single DNA sample. Extracted genomic DNA was detected by $1 \%$ agarose gel electrophoresis. PCR was carried out on a GeneAmp 9700 PCR system. Based on previous reports, the primers 338F (5'-ACTCCTACGGGAGGCAGCA-3')-806R (5'-GGACTACHVGGGTWTCTAAT-3') were used for the $16 \mathrm{~S}$ rRNA genes. Amplified products were detected by $2 \%$ agarose gel electrophoresis and recovered from the gel using the AxyPrep DNA gel extraction kit, washed with Tris- $\mathrm{HCl}$, and verified by $2 \%$ agarose gel electrophoresis. PCR products were quantified using the QuantiFluorTM-ST fluorometer, and the samples were adjusted as needed for sequencing. Sequencing was conducted by Shanghai Majorbio Biopharm Technology (Shanghai, China) using an Illumina MiSeq platform.

\section{Processing of sequencing data}

The raw sequence files were analysed and quality-filtered using QIIME (version 1.9.1) with the following criteria: (i) the 250-bp reads were truncated at any site receiving an average quality score of b20 over a 50-bp sliding window; (ii) the exact barcode matching two nucleotide mismatches in primer matching reads containing ambiguous characters were removed; and (iii) only sequences with N10 bp overlap were assembled according to their overlap sequence. Reads that could not be assembled were discarded. The chimeric sequences were identified and removed using UCHIME software. The operational taxonomic units (OTUs) with a 97\% similarity cut-off were clustered using UPARSE software. The representative sequence of each OTU was taxonomically classified by the Ribosomal Database Project (RDP) classifier against the SILVA (SSU123) database for 16S rRNA and the UNITE database for ITS rRNA using a confidence threshold of $70 \%$. The sequencing depth of the soil bacteria and fungi in all samples was $\mathrm{N} 98 \%$, indicating that they were reliable sequencing results.

\section{Statistical analyses}

Mothur software was used to calculate the community richness parameters (Chao1, Ace index) and community diversity parameters (Simpson, Shannon index) as part of the alpha diversity analysis. PCoA and h-cluster analysis are based on the Bray-Curtis matrix and were implemented using $\mathrm{R}$ software. The bioenv method was used to test the soil environmental factors, and the environmental factors with significant differences were selected for CCA. One-way analysis of variance (ANOVA) was used to analyse the differences in the diversity of both soil bacterial and fungal communities among the plough, grassland, and forest sites. Tukey's HSD (honestly significant difference) test was used for multiple comparisons when the homogeneity of variance test was successful, and significance was observed at $P$ $=0.05$. Stepwise regressions were performed to identify the best independent soil factors affecting soil bacterial and fungal diversity. One-way ANOVA, Tukey's HSD test and stepwise regressions were conducted using SPSS 16.0. The functions of bacteria and fungi were analysed using PICRUSt and FUNGuild function prediction software, respectively.

\section{Abbreviations}


$\mathrm{MC} \rrbracket$ moisture content $₫ \mathrm{MBC} \llbracket$ micro biomass carbon; $\mathrm{MBN}$ : microbiomass nitrogen: SOC: soil organic carbon: TN: total nitrogen; $\mathrm{NH}_{4}{ }^{+}-\mathrm{N}$ : Ammonium nitrogen; $\mathrm{NO}_{3}{ }^{-}-\mathrm{N}$ : Nitrate nitrogen; TP: total phosphorus; AP: available phosphorus; TK: total potassium; AK: available potassium.

\section{Declarations}

\section{Ethics approval and consent to participate}

Sampling permission has been obtained for qiqihaer in Heilongjiang Province, Northeastern China and field studies were conducted in accordance with local legislation.

\section{Consent for publication}

Consent

\section{Availability of data and materials}

All data generated or analyzed during this study are included in this published article and its supplementary information files. The raw data are available from the corresponding author on reasonable request.

\section{Competing interests}

The authors declare that they have no competing interests.

\section{Funding}

This research was supported by grants from Natural Science Foundation of Heilongjiang Province (TD2019C002), National Natural Science Foundation of China (31971527). Both of above supported the writing and publishing of papers.

\section{Authors' contributions}

ZT, SX and SFQ designed the project. ZT and LYF carried out the experiments. ZT, SX and SFQ participated in the data analysis and wrote the manuscript. All authors read and approved the final manuscript.

\section{Acknowledgments}

Thanks to Springer Nature Authoe Services editors for modifying the language of this article.

\section{References}

1. Wang Y. Long-term no-tillage and organic input management enhanced the diversity and stability of soil microbial community. Sci Total Environ. 2017; 609: 341. 
2. De Menezes AB, Richardson AE, Thrall PH. Linking fungal-bacterial co-occurrences to soil ecosystem function. Curr Opin Microbiol. 2017; 37, 135-141.

3. Lucas W, Mendes, Maria JLB, Eiko EK, Siu MT. Land-use system shapes soil bacterial communities in southeastern amazon region. Appl Soil Ecol. 2015; 95, 151-160.

4. Guo Y, Chen X, Wu Y, Zhang L, Cheng J, Wei G, Lin Y. Natural revegetation of a semiarid habitat alters taxonomic and functional diversity of soil microbial communities. Sci Total Environ. 2018; 635, 598.

5. Tian Q, Taniguchi T, Shi WY, Li G, Yamanaka N, DuS. Land-use types and soil chemical properties influence soil microbial communities in the semiarid loess plateau region in china. Sci Rep. 2017; 7, 45289.

6. Guo X, Chen HYH, Meng M, Biswas SR. Ye L, Zhang J. Effects of land use change on the composition of soil microbial communities in a managed subtropical forest. Forest Ecol Manag. 2016; 373, 93-99.

7. Mganga KZ, Razavi BS, Kuzyakov Y. Land use affects soil biochemical properties in Mt. Kilimanjaro region. Catena. 2016; 141: 22-29.

8. Jangid K, Williams MA, Franzluebbers AJ, Schmidt TM, Coleman DC, Whitman WB. Land-use history has a stronger impact on soil microbial community composition than aboveground vegetation and soil properties. Soil Biol 2011; 43(10), 2184-2193.

9. Wang K, Zhang Y, Tang Z, Shuangguan Z, Chang F, Jia F. Effects of grassland afforestation on structure and function of soil bacterial and fungal communities. Sci Total Environ. 2019; 676(AUG.1):396-406.

10. Mendes LW, Brossi MJD, Kuramae EE, Tsai SM. Land-use system shapes soil bacterial communities in southeastern Amazon region. Appl Soil Ecol. 2015; 95, 151-160.

11. Wang DW, Wang J, Li G. Calculation and Analysis of Dynamic Balance of Grain Total--A Study on the Countermeasures of Food Security Development in the West of Heilongjiang Province. Heilongjiang Science and Teclnology of Water Conservancy. 2007; 35(6):9-10.

12. Li YJ, Cui L, Li LY. Study on the development trend of land desertification in the western part of Heilongjiang Province. Protection Forest Science and Technology. 2008; (5):98-100.

13. Achard, Frédéric, Beuchle, René, Mayaux P, Stibig, Hans-Jürgen, Bodart C, Brink A. Determination of tropical deforestation rates and related carbon losses from 1990 to 2010. Global Change Biolo. 2014; 20(8), 2540-2554.

14. Xu X, Schimel JP, Thornton PE, Song X, Yuan F, Goswami S. Substrate and environmental controls on microbial assimilation of soil organic carbon: a framework for earth system models. Ecology Letters. 2014; 17(5), 547-555.

15. Gunina A, Smith AR, Godbold DL, Jones DL, Kuzyakov Y. Response of soil microbial community to afforestation with pure and mixed species. Plant Soil. 2017; 412(1-2), 357-368.

16. He D, Xiang X, He JS, Wang C, Cao G, Adams J. Composition of the soil fungal community is more sensitive to phosphorus than nitrogen addition in the alpine meadow on the qinghai-tibetan plateau. Biol Fert Soils. 2016; 52(8), 1059-1072. 
17. Zhong Y, Yan W, Wang R, Wang W, Shangguan Z. Decreased occurrence of carbon cycle functions in microbial communities along with long-term secondary succession. Soil Biol Biochem. 2018; 123, 207-217.

18. Uroz S, Buée M, Deveau A, Mieszkin S, Martin F. Ecology of the forest microbiome: highlights of temperate and boreal ecosystems. Soil Biol Biochem. 2016; 103, 471-488.

19. Hartmann M, Niklaus PA, Zimmermann S, Schmutz S, Kremer J, Abarenkov K. Resistance and resilience of the forest soil microbiome to logging-associated compaction. ISME J. 2014; 8(1), 226244.

20. Zeng Q, An S, Liu Y. Soil bacterial community response to vegetation succession after fencing in the grassland of China. Sci Total Environ. 2017; 609: 2-10.

21. Zhang Y, Dong S, Gao Q, Liu S, Zhou H, Ganjurjav H. Climate change and human activities altered the diversity and composition of soil microbial community in alpine grasslands of the qinghai-tibetan plateau. Sci Total Environ. 2016; 562, 353-363.

22. Li HY, Yao T, Ma YC, Zhang HR, Lu XW, Yang XL, Xia DH, Zhang JG, Gao YM. Soil bacterial community changes across a degradation gradient in alpine medow grasslands in the central Qilian Mountains. Acta Prataculturae Sinica. 2019; 28(8):170-179

23. He BY, Duan XW, Rong L, Zhang RH, Lu HJ. Land use controls soil bacterial diversity in the dry-hot valley region. Southwestern China. Arch Agron Soil Sci. 2020; 66(5):694-705.

24. Dang P, Yu X, Le H, Liu J, Zhao Z. Effects of stand age and soil properties on soil bacterial and fungal community composition in chinese pine plantations on the loess plateau. Plos One. 2017; 12(10), e0186501.

25. Liu Y, Huang YM, Zeng QC. Soil bacterial communities under different vegetation types in then loess plateau. Environ Sci. 2016; 37(10): 3931-3938.

26. Fierer NBM, Jackson RB. Toward an ecological classification of soil bacteria. Ecology. 2007; 88(6):13541364.

27. Fei YC, Wu QZ, Zhang X, Lu J, Ji CS, Lin KM,Cao SJ,Lin SZ, Cao GQ. Effects of different undergrowth vegetation management measures on soil characteristics and timber outturn of Cunninghamia lanceolata large-diameter timber cultivation plantation. Journal of Applied Environmental Biology. 2020; 1(07), 1-12.

28. Fu Z, Li SY, Sun XY, Hu N, Zhang JD, Li J, Zhang L. Characteristics of soil bacterial community structure in road greenbelt with in 5ring road of Beijing. Journal of Northwest Forestry University. 2019; 34(05):255-262.

29. Navarrete AA, Kuramae EE, Mattias DH, Pijl AS, Van VJA, Tsai SM. Acidobacterial community responses to agricultural management of soybean in amazon forest soils. FEMS Microbiol Ecol. 2018; (3), 3.607-621.

30. Pankratov TA, Ivanova AO, Dedysh SN, Liesack W. Bacterial populations and environmental factors controlling cellulose degradation in an acidic sphagnum peat. Environ Microbiol. 2011; 13(7), 18001814. 
31. Maestre FT, Manuel DB, Thomas CJ, David JE, Brajesh KS. Increasing aridity reduces soil microbial diversity and abundance in global drylands. P Natl A Sci. 2015; 112(51), 15684-15689.

32. Clegg CD, Lovell RDL, Hobbs PJ. The impact of grassland management regime on the community structure of selected bacterial groups in soils. Fems Microbiol Ecol. 2018; 43(2): 263-270.

33. Cui Y, Fang L, Guo X, Wang X, Wang Y, Zhang Y. Responses of soil bacterial communities, enzyme activities, and nutrients to agricultural-to-natural ecosystem conversion in the loess plateau, china. $J$ Soil Sediment. 2019; 19(3), 1427-1440.

34. Liu MH, Sui X, Hu YB, Feng FJ. Microbial community structure and the relationship with soil carbon and nitrogen in an original Korean pine forest of Changbai Mountain, China. BMC Microbiol. 2019;19(1), 218.

35. Li XZ, Rui JP, Mao YJ, Yannarell A, Mackie R. Dynamics of the bacterial community structure in the rhizosphere of a maize cultivar. Soil Biol Biochem. 2014; 68, 392-401.

36. Li X, Jiao Y, Dai G, Yang MD, Wen HY. Soil bacterial community diversity under different degrees of saline-alkaline in the Hetao Area of Inner Mongolia. China Environmental Science. 2016; 36(1): p. 249-260.

37. Michael M, Obermeier FG, Abilash C, Durai R, Wolfgang AO, Christoph AO, Schmid HB, Peter S. Under temperate climate, the conversion of grassland to arable land affects soil nutrient stocks and bacteria in a short term. Sci Total Environ. 2019;11-15.

38. Pascault N, Cécillon L, Mathieu O, Hénault C, Sarr A, Lévêque J, Farcy P, Ranjard L, Maron PA. In Situ Dynamics of Microbial Communities during Decomposition of Wheat, Rape, and Alfalfa Residues. Microb Ecol. 2010; 60(4): 816-828.

39. Corstanje R, Reddy KR, Prenger JP, Newman S, Ogram AV. Soil microbial eco-physiological response to nutrient enrichment in a sub-tropical wetland. Ecol Indic. 2007; 7(2), 0-289.

40. Palaniyandi SA, Damodharan K, Yang SH, Suh JW. Streptomyces sp. strain pgpa39 alleviates salt stress and promotes growth of 'micro tom' tomato plants. J Appl Microbiol. 2014; 117(3), 766-773.

41. Jošić $D$, Ćirić A, Soković M, Stanojković-Sebić A, PivićR, Lepšanović Z, Glamočlija Antifungal activities of indigenous plant growth promoting Pseudomonas spp. from alfalfa and clover rhizosphere. Front Life Sci. 2015; 8(2): 131-138.

42. Mahoney AK, Chuntao Y, Hulbert SH. Community structure, species variation, and potential functions of rhizosphere-associated bacteria of different winter wheat (triticum aestivum) cultivars. Front Plant Sci. 2017; 8(9743), 132.

43. Monreal CM, Zhang J, Koziel S, Vidmar J, González M, Matus F, Baxic S, Wu S, DeRosa M, Etcheverria P. Bacterial community structure associated with the addition of nitrogen and the dynamics of soluble carbon in the rhizosphere of canola (Brassica napus) grown in a Podzol. Rhizosphere. 2017; 16-25.

44. Li X, Zhang HH, Sun ML, Xu N, Sun GY, Zhao MC. Land use change from upland to paddy field in Mollisols drives soil aggregation and associated microbial communities. Appl Soil Ecol. 2020; 146. 
45. Turner TR, Ramakrishnan K, Walshaw J, Heavens D, Alston M, Swarbreck D. Comparative metatranscriptomics reveals kingdom level changes in the rhizosphere microbiome of plants. ISME J. 2013; 7(12), 2248-2258.

46. Donn S, John AK, Perera G, Alan ER, Michelle W. Evolution of bacterial communities in the wheat crop rhizosphere. Environ Microbiol. 2015; 17(3), 610-21.

47. Gkarmiri K, Mahmood S, Ekblad A, AlstrM S, Gberg N, Finlay R. Identifying the active microbiome associated with roots and rhizosphere soil of oilseed rape. Appl Environ Microb. 2017; 01938-17.

48. Xiao X, Chen W, Zong L, Yang J, Jiao S, Lin Y. Two cultivated legume plants reveal the enrichment process of the microbiome in the rhizocompartments. Mol Ecol. 2017; 26(6), 1641-1651.

49. Bergkemper FWG, Lang F, Krüger J, Schloter M, Schulz S. The importance of C, N and P as driver for bacterial community structure in German beech dominated forest soils. J Plant Nutr Soil Sc. 2016; $179(4): 472-480$.

50. Cao HY, Gao GL, Ding GD, Zhang Y, Zhao YY, Ren Y, Chen Y, Guo M S. Community Structure and Diversity of Soil Fungi in Four Habitats in Hulun Buir Sandy Land. Scientia Silvae Sinicae. 2019; 55(08):118-127.

51. Rainey FA, Ray K, Ferreira M, Gatz BZ, Nobre F, Bagaley D. Extensive diversity of ionizing-radiationresistant bacteria recovered from sonoran desert soil and description of nine new species of the genus deinococcus obtained from a single soil sample. Appl Environ Microb. 2005; 71(11), 76307630.

52. Zhang KR, Cheng XL, Shu X. Linking soil bacterial and fungal communities to vegetation succession following agricultural abandonment. Plant Soil. 2018.

53. Zumsteg A, Luster J, Ransson H, Smittenberg RH, Brunner I, Bernasconi SM. Bacterial, archaeal and fungal succession in the forefield of a receding glacier. Microb Ecol. 2012; 63(3), 552-564.

54. Zhang WQ, Luo GT, Yu Y, Yan W. Morphological type and molecular identification of ectomycorrhiza on Pinus sylvestris var.mongolica. Acta Agriculturae Zhejiangensis. 2017; 29(10).

55. Dimitrios F, Manfred B, Robert R, Kerrie B, Robert AB, Bernard H, Angel TM. The Paleozoic Origin of Enzymatic Lignin Decomposition Reconstructed from 31 Fungal Genomes. Science. 2012; 336(6089): 1715-1719.

56. Treseder KK, Lennon JT. Fungal Traits That Drive Ecosystem Dynamics on Land. Microbiol Mol Biol Rev. 2015; 79(2): 243-262.

57. Angela LT, Simona P, Anna MP, Francesco C, Solveig T, Enrica C. A meta-barcoding analysis of soil mycobiota of the upper Andean Colombian agro-environment. Sci REP. 2019; 9(1).

58. Qian YL, Wang XZ, Lai XF, Li JC, Shen YY. Effects of perennial forage on characteristics of the soil fungal community in an apple orchard. Acta Prataculturae Sinica. 2019; 28(11):124-132.

59. Xiao L, Huang YM, Zhao JF, Zhou JY, Guo ZH, Liu Y. High-throughput sequencing sevealed soil fungal communities under three terrace agrotypes on the loess plateau. China Environmental Science. 2017; 37(8), 3151-3158. 
60. Cai JJ, Dong LG, Li SB, Pan ZB, Xu H, Zhang YR. The Characteristics of Soil Microbe Function Diversity in Semi-arid Loess Hilly Region. Ecology and Environmental Sciences. 2016; 04.

61. Degrune F, Dufrêne M, Colinet G, Massart S, Taminiau B, Bodson B. A novel sub-phylum method discriminates better the impact of crop management on soil microbial community. Agrono Sustain Dev. 2015; 35(3), 1157-1166.

62. Zhang W, Lu Z, Yang K, Zhu J. Impacts of conversion from secondary forests to larch plantations on the structure and function of microbial communities. Appl Soil Ecol. 2017; 111, 73-83.

63. Hogberg MN, Hogberg P, Myrold DD. Is microbial community composition in boreal forest soils determined by $\mathrm{pH}$, C-to-N ratio, the trees, or all three? Oecologia. 2007; 150(4)ष590-601.

64. Rousk J, Brookes PC, Erland B. Contrasting soil ph effects on fungal and bacterial growth suggest functional redundancy in carbon mineralization. Appl Environ Microb. 2009; 75(6), 1589-1596.

65. Baldrian P. Microbial activity and the dynamics of ecosystem processes in forest soils. Curr Opin Microbiol. 2017; 37, 128-134.

66. Leho T, Mohammad B, Sergei P, Urmas K, Nourou SY, Ravi W, Luis V. Global diversity and geography of soil fungi. Science. 2014; 346(6213): 1256688-1256688.

67. Liang HB, Yan JW, Luo LX. Characterizing the Intra-Vineyard Variation of Soil Bacterial and Fungal Communities. Front in microbiol. 2019; 10.

68. Li F. Succession of Upland Soil Microbial Structure under Long-term Fertilization in Huang-huai-hai Plain. Henan, Henan Agricultural University. 2016.

69. Xu TW, Hao HH, Wu XX, Li GY. Investigation and Prevention of Fungal Diseases on Golf Course Lawn in Hainan Province. Journal of Henan Agricultural Sciences. 2017; 46(12).

70. Feng HW, Wang DX, Mao L, Zhi Y, Zhou P. Influence of organic cultivation on soil microbial community in cornfield. Journal of Shanghai Jiaotong University. 2016.

71. Jiang YU, Zhen-Hua YU, Makoto I, Masao S, Liu XB, Wang GH. Effects of manure application on the diversity of corn root endophytic bacterial communities at seedling stage in eroded mollisols. Chinese J Appl Ecol. 2016; 27(8), 2663-2669.

72. Barka EA, Vatsa P, Sanchez L, Gaveau-Vaillant N, Wezel GPV. Taxonomy, physiology, and natural products of actinobacteria. Microbiology and molecular biology reviews: MMBR. 2015; 80(1), 1-43.

73. Rousk JBTE, Brookes PC, Lauber CL, Lozupone C, Caporaso JG. Soil bacterial and fungal communities across a pH gradient in an arable soil. ISME J. 2010; 4(10):1340-1351.

74. Kayla NB, Daniel AK, Sarah LS, Nicholas AB, Dario C, Kerri LS. Vineyard soil bacterial diversity and composition revealed by $16 \mathrm{~S}$ rRNA genes: Differentiation by vineyard management. Soil Biol Biochem. 2015; 103: 337-348.

75. Liu Q, Qiao N,Xu XL, Xin XP, Han JY. Nitrogen acquisition by plants and microorganisms in a temperate grassland. Sci Rep. 2016; 6: 22642.

76. Leff JW, Jones SE, Prober SM, Barberán A, Borer ET, Firn JL. Consistent responses of soil microbial communities to elevated nutrient inputs in grasslands across the globe. P Natl A Sci. 2015; 08382. 
77. Zhang Y, Dong S, Gao Q, Liu S, Zhou H, Ganjurjav H. Climate change and human activities altered the diversity and composition of soil microbial community in alpine grasslands of the qinghai-tibetan plateau. Sci Total Environ. 2016; 562, 353-363.

78. Kotze E, Sandhage-Hofmann A, Meinel JA, Preez CCD, Amelung W. Rangeland management impacts on the properties of clayey soils along grazing gradients in the semi-arid grassland biome of south africa. J Arid Environ,2013; 97, 220-229.

79. Corstanje R, Reddy KR, Prenger JP, Newman S, Ogram AV. Soil microbial eco-physiological response to nutrient enrichment in a sub-tropical wetland. Ecol Indic. 2007; 7(2), 0-289.

80. He D, Xiang X, He JS, Wang C, Cao G, Adams J. Composition of the soil fungal community is more sensitive to phosphorus than nitrogen addition in the alpine meadow on the qinghai-tibetan plateau. Biol Fert Soils. 2016; 52(8), 1059-1072.

\section{Figures}

A

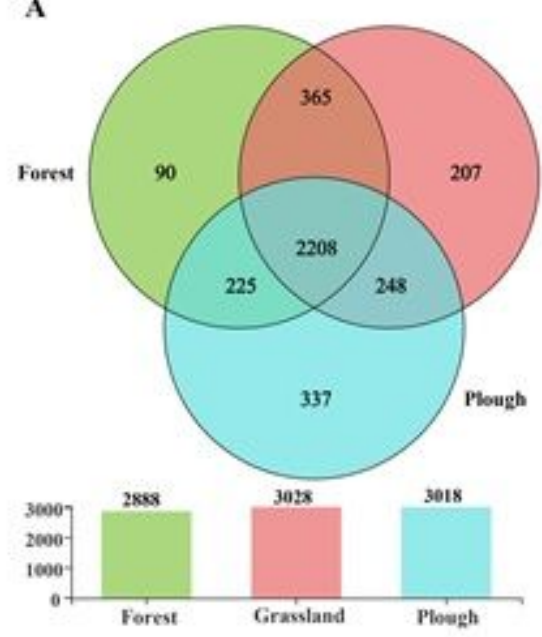

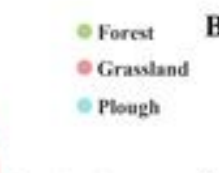
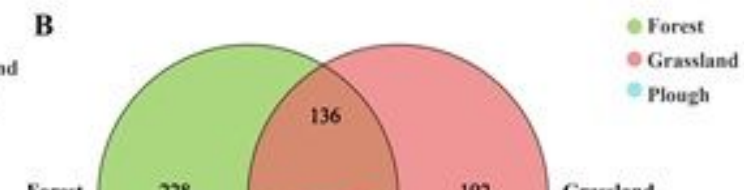

Grassland
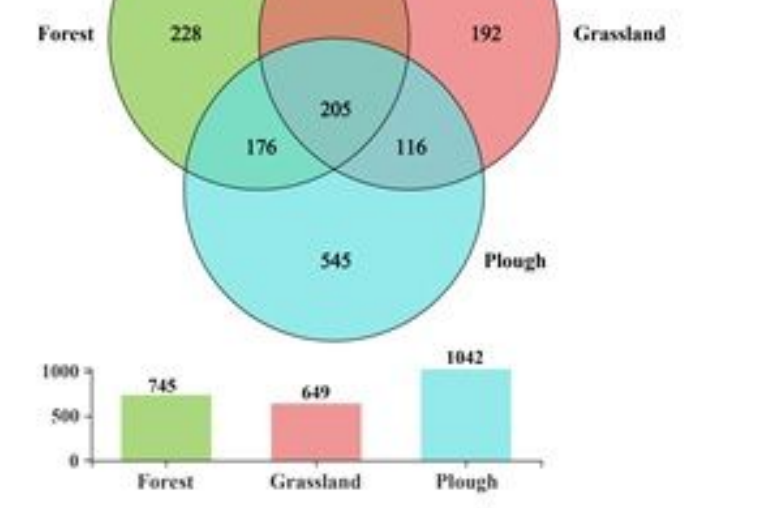

\section{Figure 1}

OTU Venn analyses of the soil bacterial (A) and fungal (B) community in the three land use patterns. Note: in the figure above, different colors represent different groups, the Numbers of overlapping parts represent the number of species that are common to multiple groups, and the Numbers of nonoverlapping parts represent the number of species that are unique to each group.In the figure below, the abscissa is the number of common or unique groups, and the length of the horizontal column above represents the corresponding number of species 

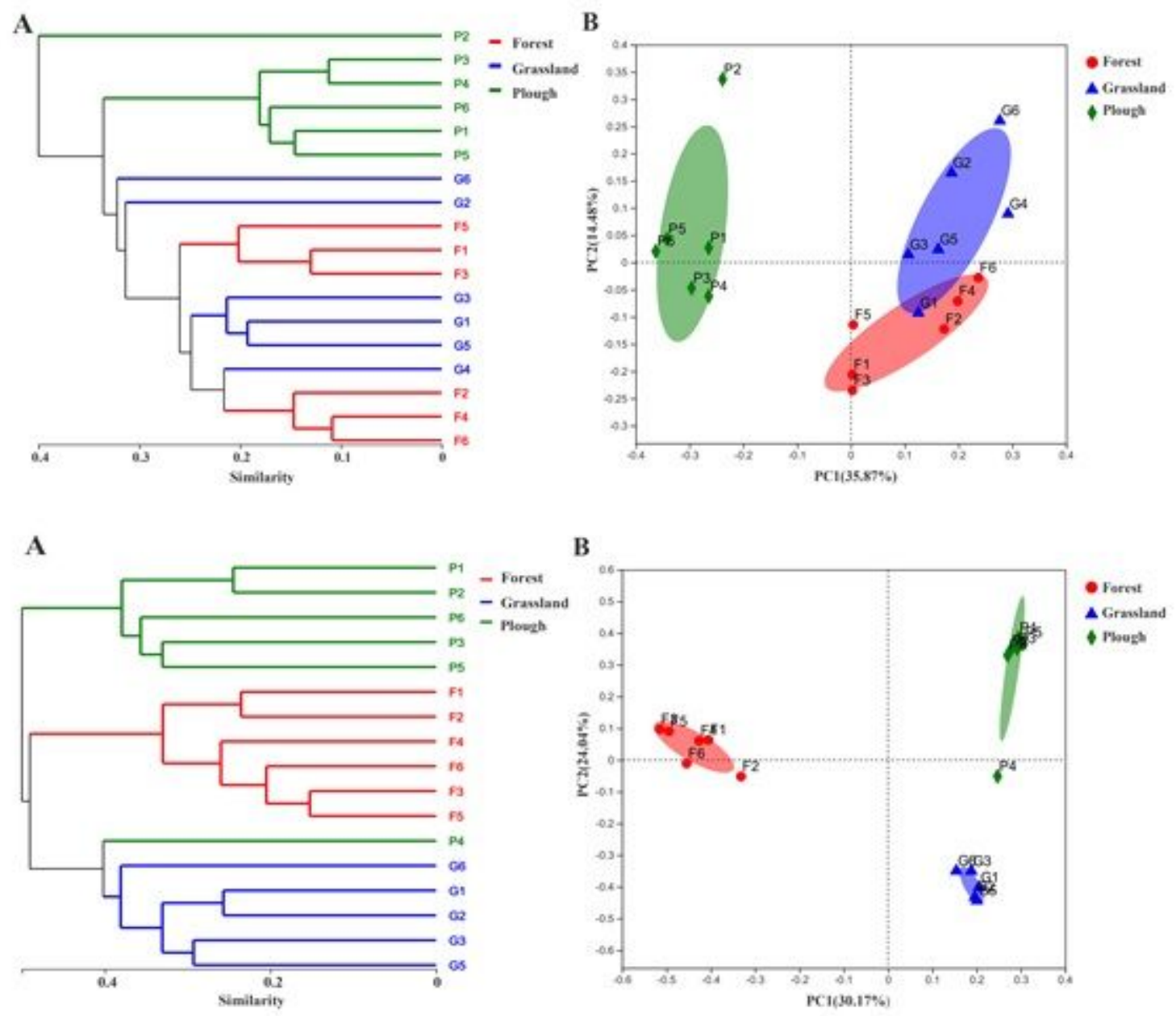

Figure 2

soil bacterial community clustering tree (A) and PCoA diagram (B) and fungal community clustering tree (C) and PCoA diagram (D) in different land use patterns Note: the length of the branches in the community clustering tree represents the distance between the samples. Different groups can be presented in different colors. The $\mathrm{X}$ axis and $\mathrm{Y}$ axis in the PCoA diagram represent the two selected main coordinate axes, and the percentage represents the interpretation value of the main coordinate axis to the difference in sample composition; Color or shape points represent samples of different groups, the closer the two sample points are, the more similar the species composition of the two samples 

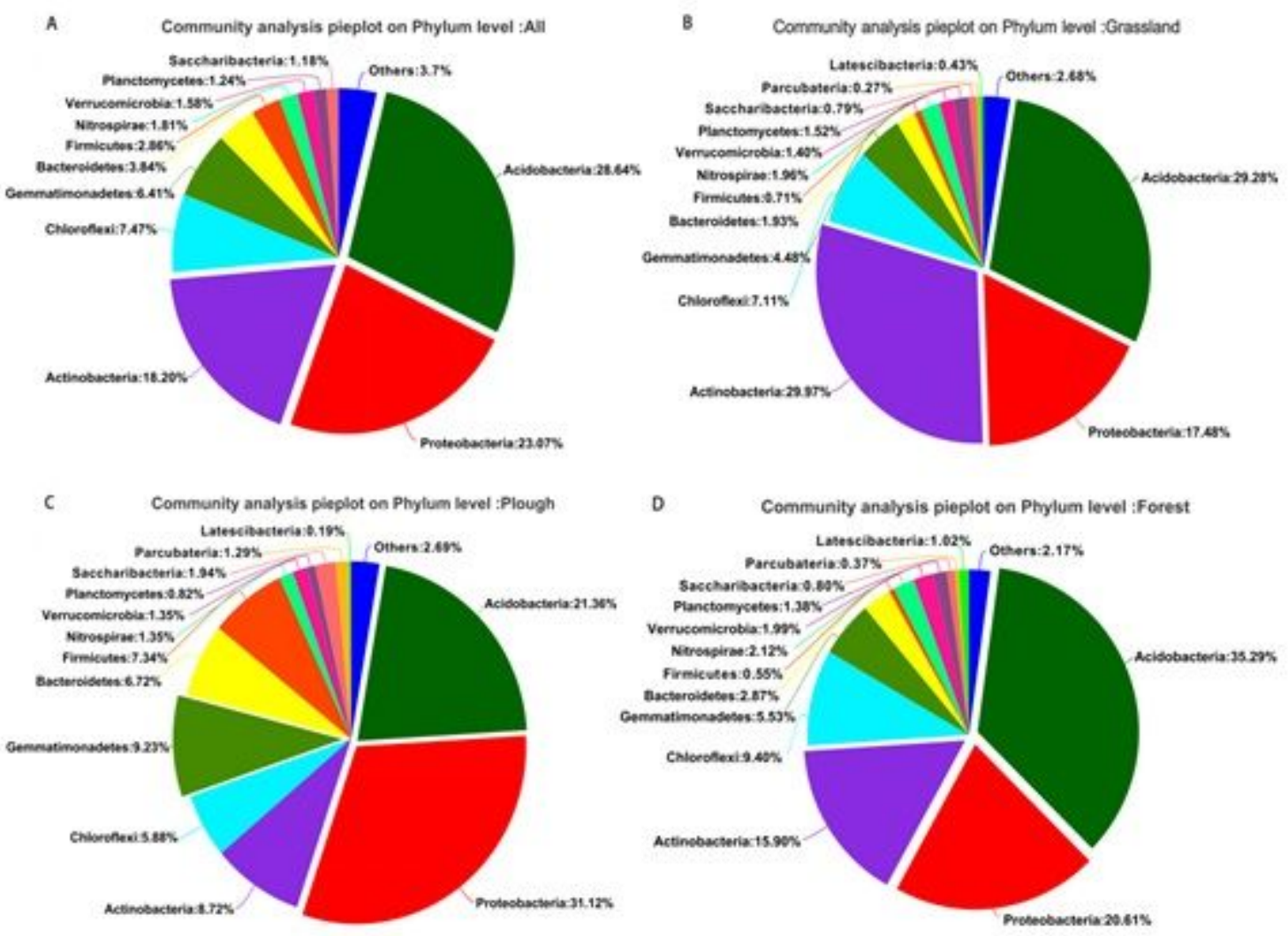

\section{Figure 3}

Community structure composition at the level of bacterial phylum at different land uses patterns Note: A general; $\mathrm{B}$ grassland; $\mathrm{C}$ plough; $\mathrm{D}$ forest, and the gate abundance is less than $1 \%$ and merged into other. The same below. 

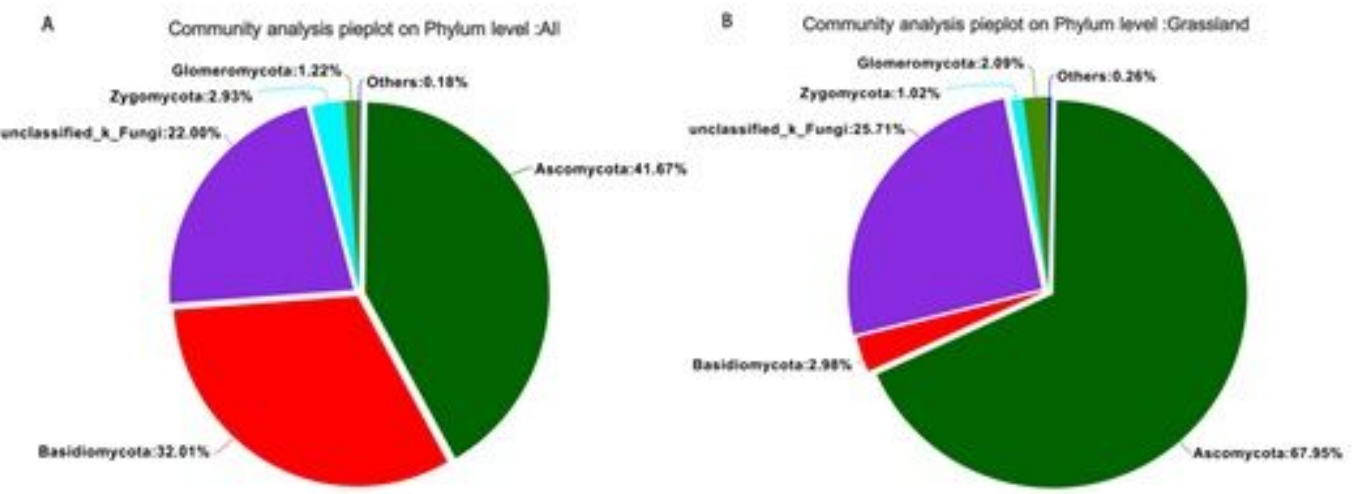

C Community analysis pleplot on Phylum level : Plough

D Community analysis pieplot on Ptylum level :Focest
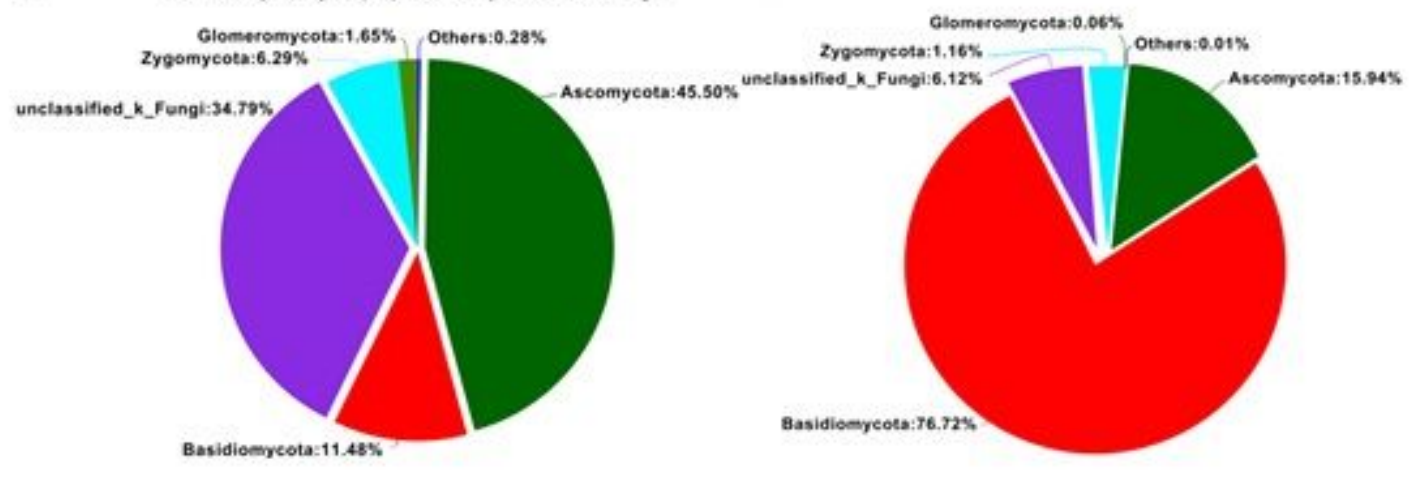

\section{Figure 4}

Community structure composition at the level of fungal phylum at different land uses patterns 

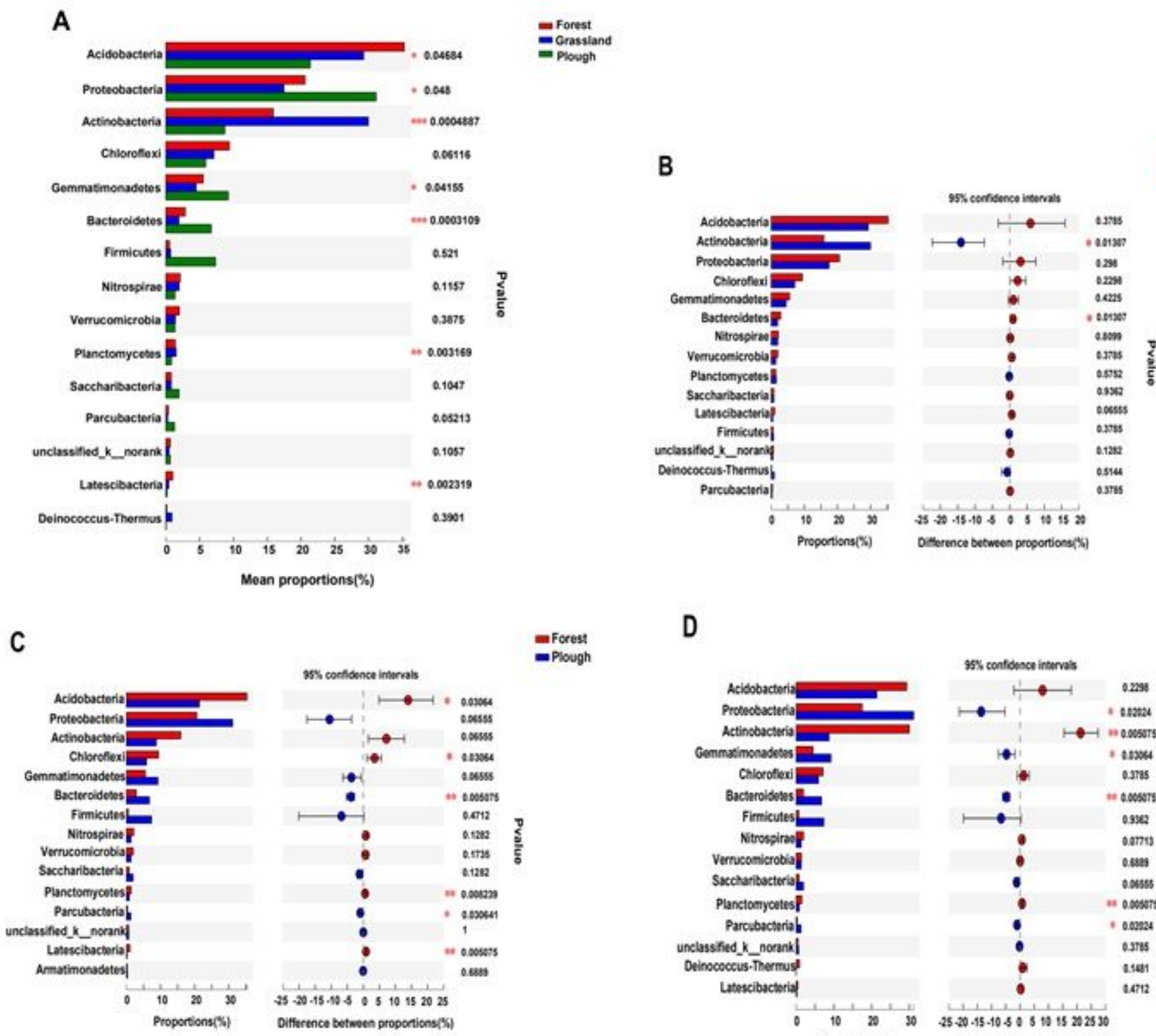

D

EForest -Plough
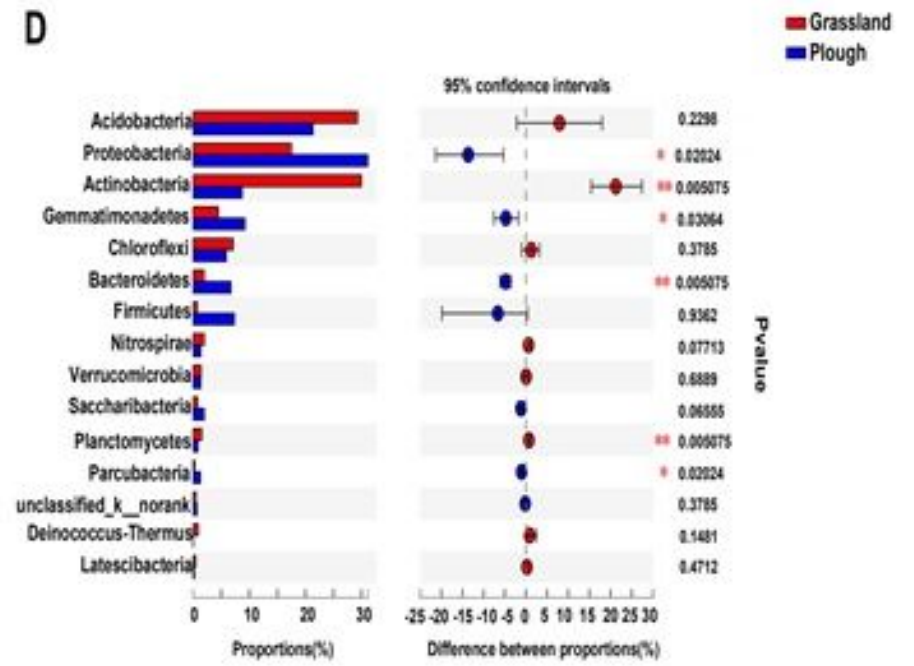

Figure 5

Differences in the level abundance of bacterial phylums in different land use patterns Note: The $Y$ axis represents the name of a species at a certain taxonomic level, the $X$ axis represents the average relative abundance of different groups of species, and the columns of different colors represent different groups; the far right is the $P$ value, $* 0.01<P \leq 0.05, * \star 0.001<P \leq 0.01, \star \star \star P \leq 0.001$. The same below. 

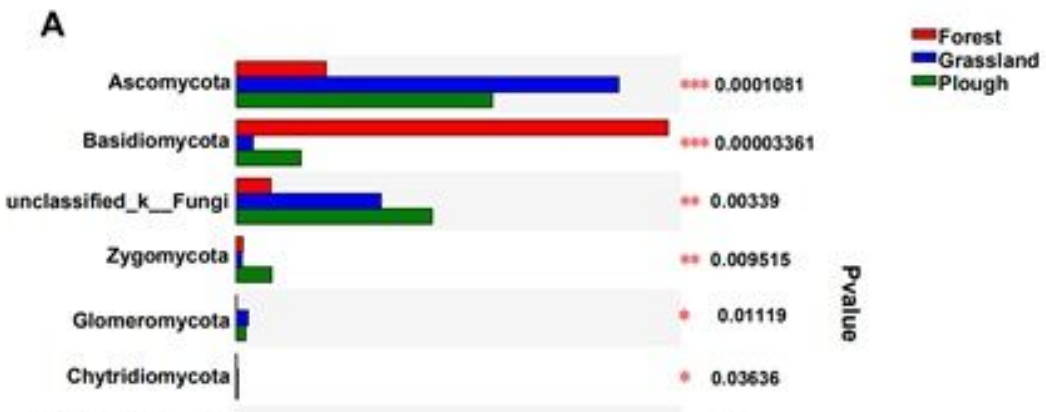

Blastocladiomycota

NA

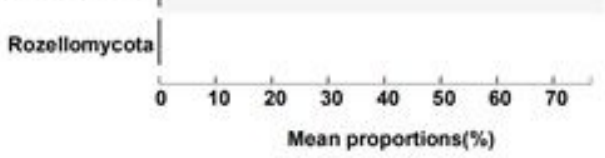

0.5821

B
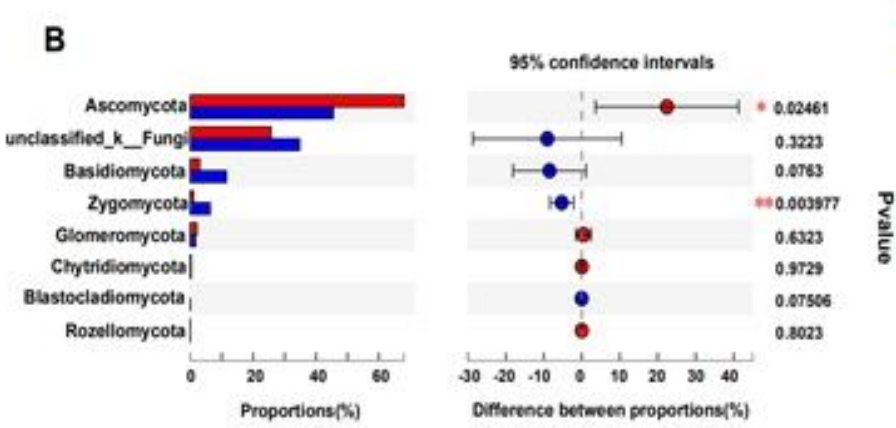

C
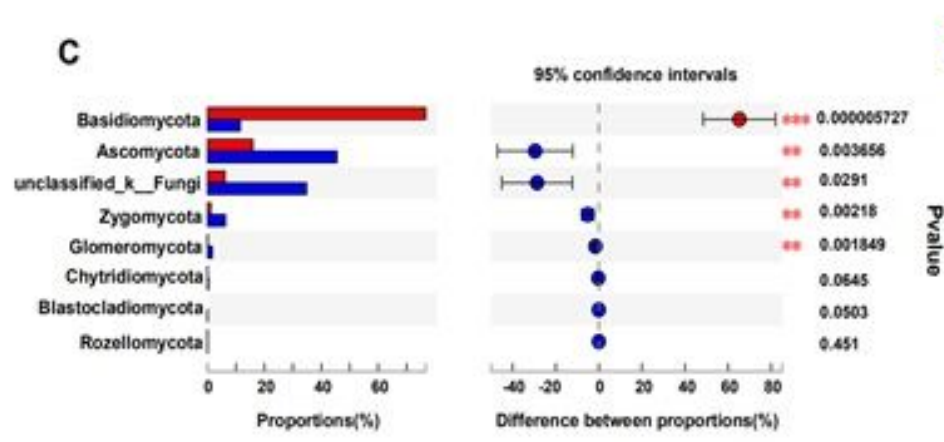

D
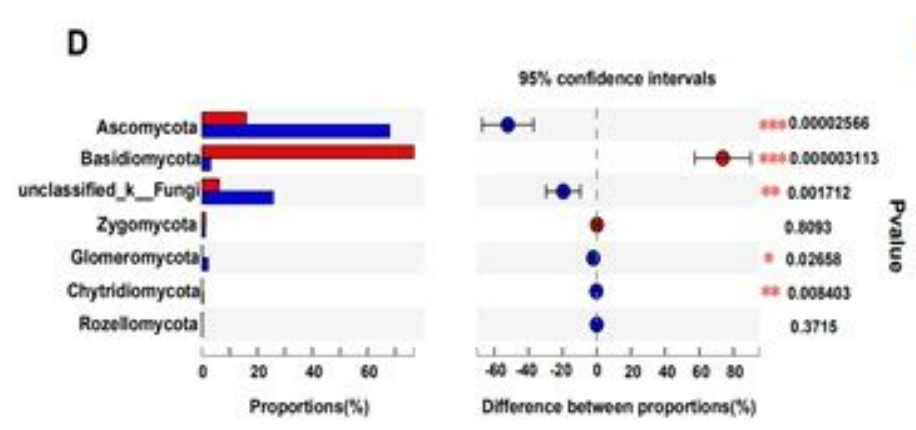

- Grassland

-Plough

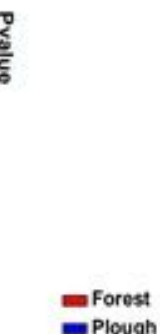

- Plough

$\frac{9}{5}$

-Forest

- Grassland

\section{Figure 6}

Differences in the level abundance of fungal in different land use patterns 
A

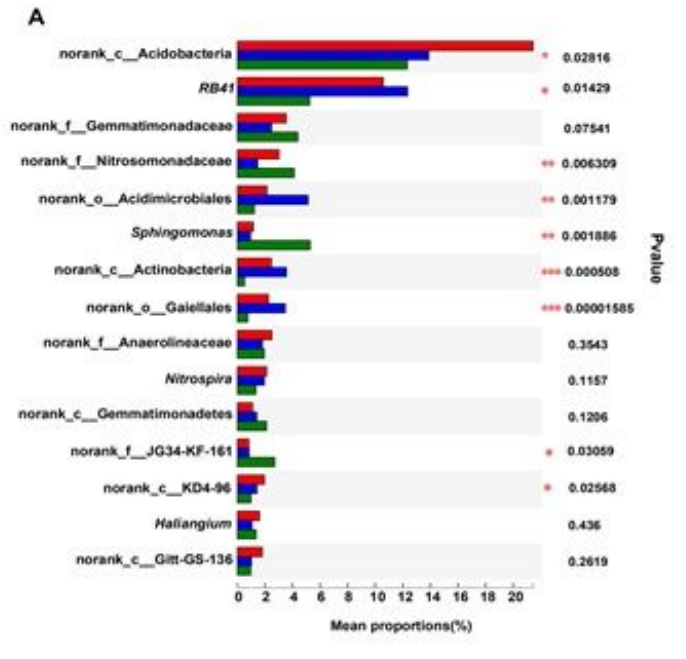

EForest
= Grassiand
aplough
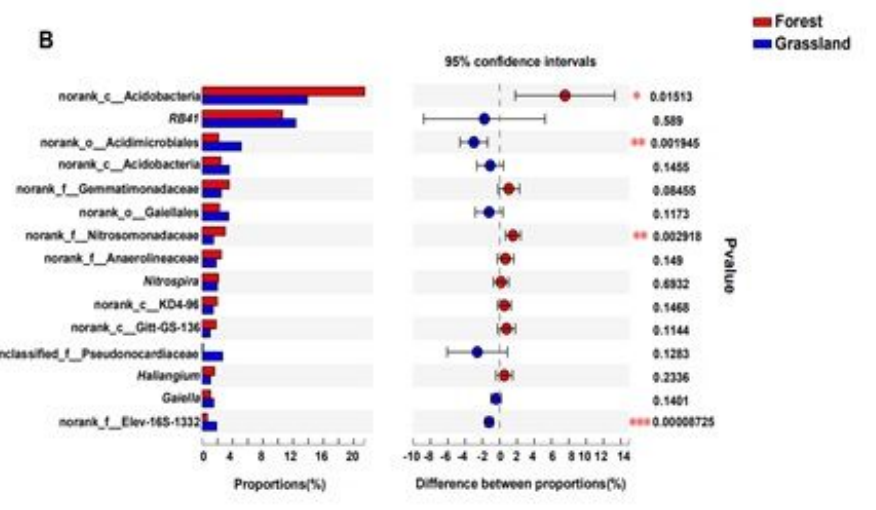

C
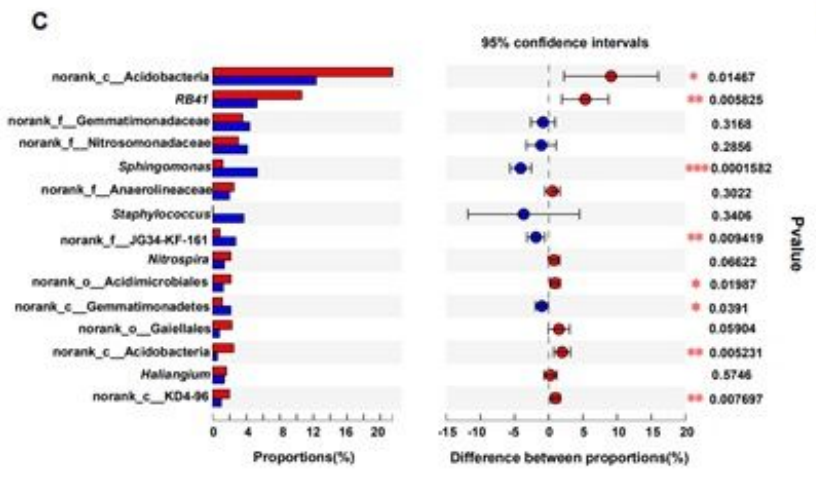

E Grassland
- Plough

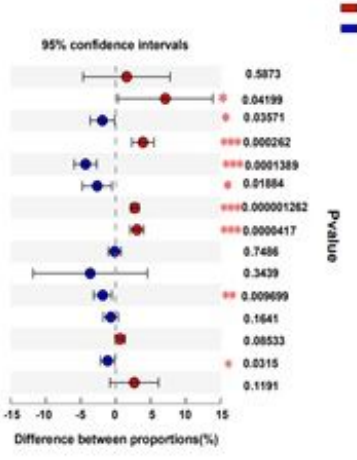

Figure 7

Differences in taxonomic abundance of bacterial communities in different land use patterns 


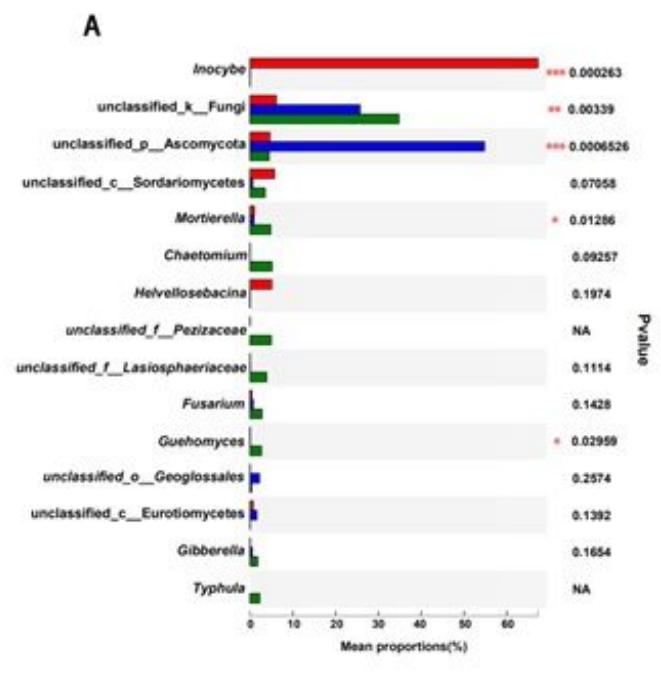

\section{EForest
E-Grassiand
Eplowih}
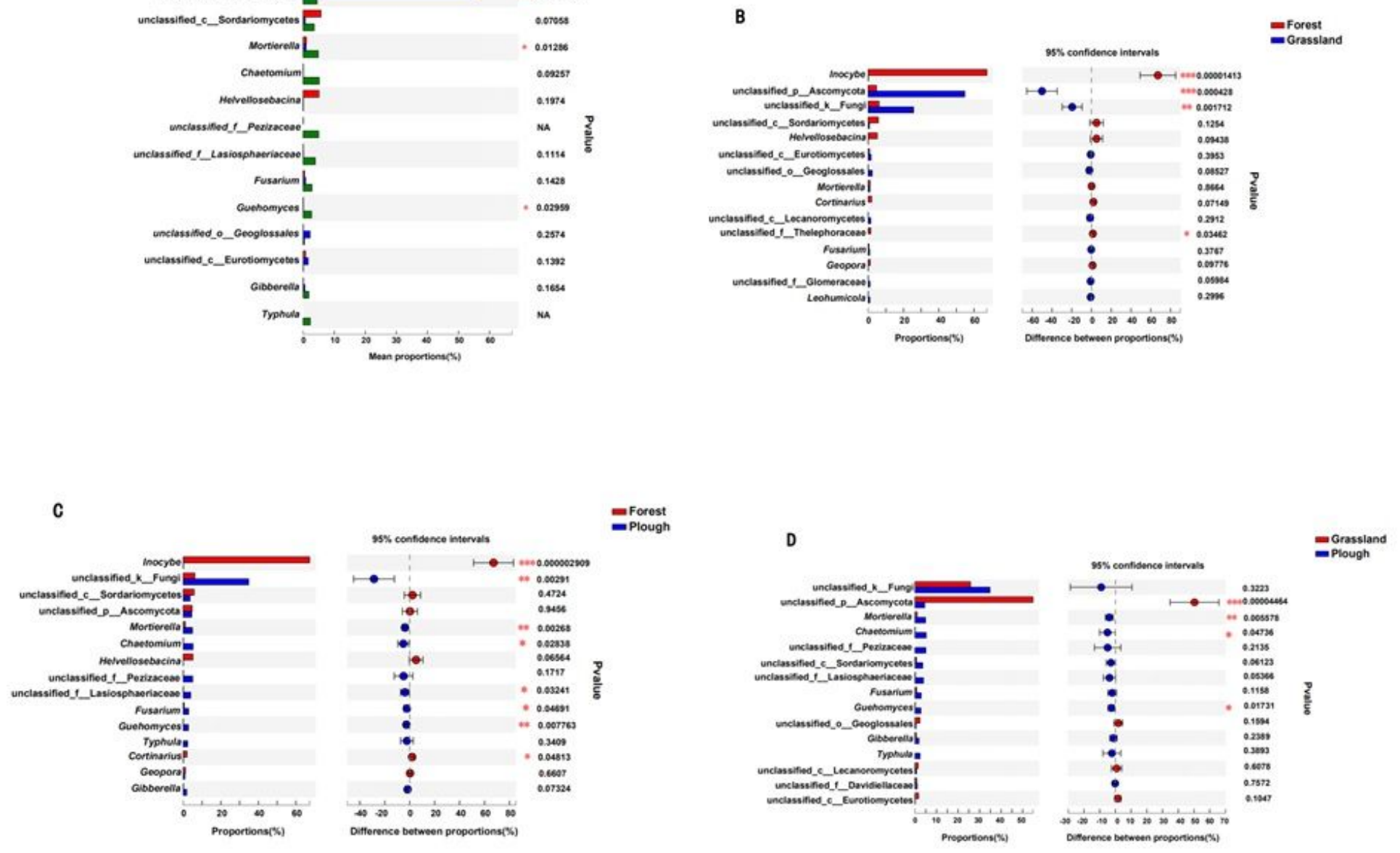

\section{Figure 8}

Differences in taxonomic abundance of fungal communities in different land use patterns 

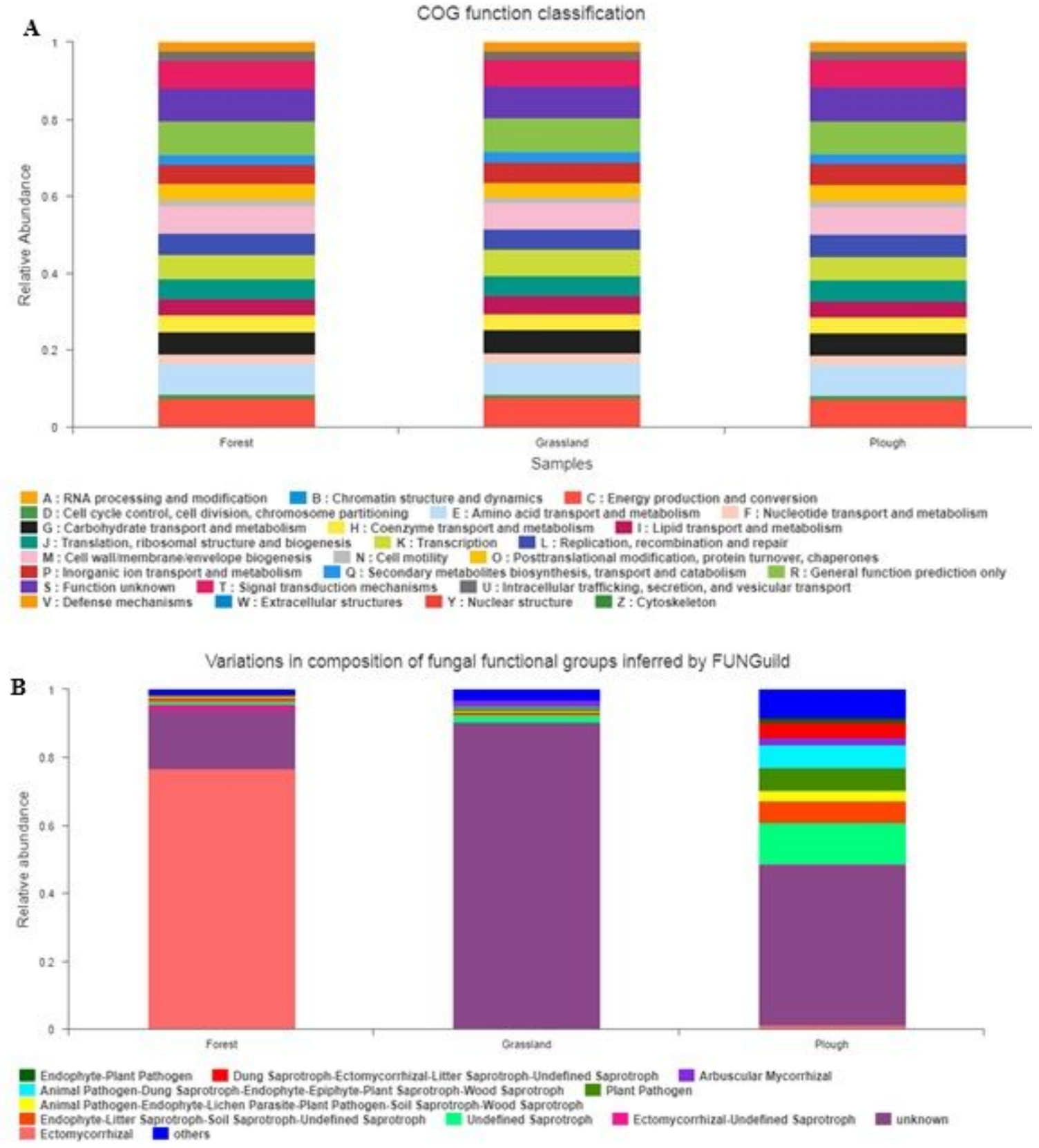

Figure 9

Community functions of soil bacteria (A) and fungal (B) under different land use patterns Note: The abscissa is the sample name, and the ordinate is the functional abundance. The color gradient of the color block is used to show the changes in the abundance of different functions in the sample 

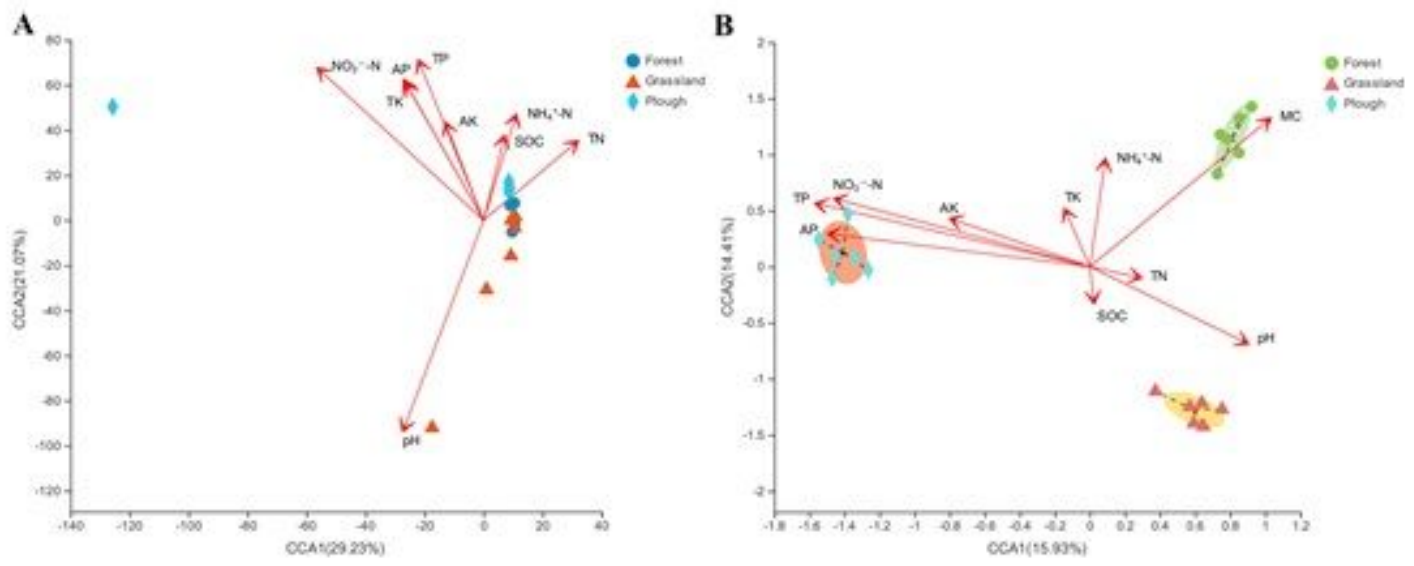

Figure 10

CCA analysis of soil bacterial (A) and fungal (B) community structure and soil physical and chemical properties Note: Arrows indicate the direction and magnitude of the environmental parameters associated with bacterial and fungal community structures, respectively. $\mathrm{MC} \triangle$ moisture content $\triangle \mathrm{MBC} \triangle$ micro biomass carbon; MBN: microbiomass nitrogen: SOC: soil organic carbon: TN: total nitrogen; TP: total phosphorus; AP: available phosphorus; TK: total potassium; AK: available potassium 